\title{
Review \\ Dexamethasone in the Treatment of COVID-19: Primus Inter Pares?
}

\author{
Vasiliki Romanou, Evangelia Koukaki, Vasiliki Chantziara (D), Panagiota Stamou, Alexandra Kote, \\ Ioannis Vasileiadis, Antonia Koutsoukou and Nikoletta Rovina *(D)
}

check for updates

Citation: Romanou, V.; Koukaki, E.; Chantziara, V.; Stamou, P.; Kote, A.; Vasileiadis, I.; Koutsoukou, A.; Rovina, N. Dexamethasone in the Treatment of COVID-19: Primus Inter Pares? J. Pers. Med. 2021, 11, 556. https://doi.org/10.3390/jpm11060556

Academic Editor: Victor E. Ortega

Received: 29 April 2021

Accepted: 13 June 2021

Published: 15 June 2021

Publisher's Note: MDPI stays neutral with regard to jurisdictional claims in published maps and institutional affiliations.

Copyright: (c) 2021 by the authors. Licensee MDPI, Basel, Switzerland. This article is an open access article distributed under the terms and conditions of the Creative Commons Attribution (CC BY) license (https:/ / creativecommons.org/licenses/by/ $4.0 /)$. 1st Department of Respiratory Medicine, Medical School, National and Kapodistrian University of Athens and "Sotiria" Chest Disease Hospital, 11527 Athens, Greece; vassoromanou@gmail.com (V.R.); e.koukaki@yahoo.gr (E.K.); vchantziara@yahoo.gr (V.C.); giwtastam@live.co.uk (P.S.); akote_1990@hotmail.com (A.K.); ioannisvmed@yahoo.gr (I.V.); koutsoukou@yahoo.gr (A.K.)

* Correspondence: nikrovina@med.uoa.gr; Tel.: +30-210-7763650

\begin{abstract}
Coronavirus disease 2019 (COVID-19), caused by severe acute respiratory syndrome coronavirus 2 (SARS-CoV-2), has rapidly spread globally, becoming a huge public health challenge. Even though the vast majority of patients are asymptomatic, some patients present with pneumonia, acute respiratory distress syndrome (ARDS), septic shock, and death. It has been shown in several studies that the severity and clinical outcomes are related to dysregulated antiviral immunity and enhanced and persistent systemic inflammation. Corticosteroids have been used for the treatment of COVID-19 patients, as they are reported to elicit benefits by reducing lung inflammation and inflammation-induced lung injury. Dexamethasone has gained a major role in the therapeutic algorithm of patients with COVID-19 pneumonia requiring supplemental oxygen or on mechanical ventilation. Its wide anti-inflammatory action seems to form the basis for its beneficial action, taming the overwhelming "cytokine storm". Amid a plethora of scientific research on therapeutic options for COVID-19, there are still unanswered questions about the right timing, right dosing, and right duration of the corticosteroid treatment. The aim of this review article was to summarize the data on the dexamethasone treatment in COVID-19 and outline the clinical considerations of corticosteroid therapy in these patients.
\end{abstract}

Keywords: dexamethasone; corticosteroids; COVID-19

\section{Introduction}

Coronavirus disease 2019 (COVID-19), caused by severe acute respiratory syndrome coronavirus 2 (SARS-CoV-2), has rapidly spread around the world since its first appearance in China [1-3]. Although the vast majority of patients present with mild symptoms, about $15 \%$ of COVID-19 cases become severe [4], with approximately $31-41.8 \%$ of hospitalized patients rapidly developing acute respiratory distress syndrome (ARDS) [1,2] with a subsequent increased risk of death. The mortality rates referring to critically ill COVID-19 patients range between $26 \%$ and $61.5 \%$ around the world [1-4].

Several studies have documented that the severity and clinical outcomes are related to dysregulated antiviral immunity and enhanced and persistent systemic inflammation [5-9], as highlighted by a decreased expression of interferons I/III and hyperinflammatory responses involving the release of proinflammatory cytokines (e.g., IL-6, IL-1, TNF, IL-8, and MCP-1) that are sustaining in time (cytokine storm). Consequently, antiviral and anti-inflammatory therapies have been implemented in the pursuit of timely and effective therapies. As yet, though, no specific pharmacological treatments have been proven efficacious for the treatment of COVID-19 [10].

In the context of inflammation being a key role player in the evolvement of severe disease, corticosteroids have been used for the treatment of COVID-19 patients, as they are reported to elicit benefits by reducing lung inflammation and inflammation-induced 
lung injury. Early enough, in the first pandemic wave, corticosteroids were introduced in the treatment of critically ill COVID-19 patients with respiratory failure in low-tomoderate doses and for short courses [4,11-13]. Wu et al. showed that the corticosteroid treatment in patients with ARDS reduced the mortality risk ( $46 \%$ in patients receiving corticosteroids vs. $61.8 \%$ in patients not receiving corticosteroids [14]. Furthermore, the Surviving Sepsis Campaign suggests the use of low-dose corticosteroid therapy in COVID19 patients with refractory shock to suppress the cytokine storm caused by SARS-CoV-2 and to improve peripheral vasodilation [15]. With the RECOVERY trial, a significant benefit of glucocorticoid dexamethasone was shown in patients with COVID-19 on mechanical ventilation or oxygen alone at the time of randomization [16]. Based on the positive results of the RECOVERY trial, the National Institutes of Health (NIH) COVID-19 Treatment Guidelines and the World Health Organization (WHO) approved the findings on the beneficial use of dexamethasone in treating critically ill patients with COVID-19 and recommended the dexamethasone treatment in hospitalized patients with respiratory failure requiring a noninvasive/high-flow oxygen device or invasive ventilation [17]. Nonetheless, several studies have reported deleterious effects caused by the corticosteroid treatment that was associated with the use of an increased dose of corticosteroids [18-20], the delay of SARS-CoV-2 viral clearance in patients receiving corticosteroids $[18,21]$, and the increased risk of secondary infections and complications due to the corticosteroid treatment. Therefore, the clinical benefit of this treatment in COVID-19 patients still remains controversial.

\section{Current Evidence}

Beyond doubt, the RECOVERY trial showed a clear benefit of dexamethasone in critically ill patients with COVID-19 on mechanical ventilation at the time of randomization as compared to the usual care (28-day mortality of $29.3 \%$ vs. $41.4 \%$ ). Similarly, patients on oxygen alone in the dexamethasone group, when compared to the usual care group, had a lower risk of progression to invasive mechanical ventilation (risk ratio, $0.79 ; 95 \% \mathrm{CI}, 0.64$ to 0.97 ), a shorter duration of hospitalization (median, 12 days vs. 13 days), and a greater probability of being alive at discharge within 28 days (rate ratio, 1.10; $95 \%$ CI, 1.03 to 1.17). No benefit was shown in patients with a milder disease without respiratory failure (28-day mortality of $17.8 \%$ vs. $14 \%$ ) [16].

Two more observational trials of corticosteroids for COVID-19 [14,22] and four review and meta-analysis studies [23-26] showed evidence of benefits in mortality. Of note, Pasin et al. in their metanalysis [24] of the five basic studies on corticosteroids ikn COVID19 [16,27-30] coincided with the RECOVERY trial results in that the survival benefits of corticosteroids exist for mechanically ventilated patients and not for patients with no oxygen need. In line with these positive results, subgroups of COVID-19 patients with ARDS [31,32], increased inflammatory markers [33], or over 60 years of age [30] had the highest benefits from corticosteroids. Improved clinical symptoms, radiological findings, and the respiratory failure of patients with COVID-19 were also reported [34,35]. In a small randomized controlled trial, improved clinical outcomes were reported in patients with COVID-19 receiving a short course of methylprednisolone [13]. Wang et al. [35] also found that the use of methylprednisolone ( 1 to $2 \mathrm{mg} / \mathrm{kg}$ /day for 5-7 days) in twenty-six severe COVID-19 patients was associated with a reduced length of hospitalization and ICU stay.

Collectively, a prospective meta-analysis of the trials by the WHO, with a total of 1703 patients ( $59 \%$ from the RECOVERY trial), confirmed a reduction in the 28-day mortality (summary odds ratio (OR) $0.66,95 \%$ CI $0.53-0.82 ; p<0.001$ ) [23].

Nevertheless, the mortality benefits of corticosteroids were not confirmed in a series of other studies [27,28,30,36-39]. The retrospective cohorts of COVID-19 patients, mostly from the first wave in China $[18,19,40,41]$, reported an increased mortality in severely ill patients taking high-dose corticosteroids. Lu, X. et al. [19] mentioned that a 10-mg increase in hydrocortisone resulted in a $4 \%$ increase in the risk of death. In accordance were the results 
of one meta-analysis study [20] based on low-quality evidence with a high variability. Tables 1-4 summarizes the trials on corticosteroid treatments in COVID-19 patients.

These results should be interpreted with caution owing to the potential bias and confounding factors, since they mostly derive from small-sized single-center observational studies; they include patients of different disease stages or severities, and furthermore, they refer to corticosteroid treatments other than dexamethasone. It is noteworthy that dexamethasone showed favorable results in the RECOVERY trial, especially in the critically ill patients, setting a novel positive view on corticosteroid use in respiratory viral infections in these patients. Hence, understanding dexamethasone's mode of action merits the uppermost importance. 


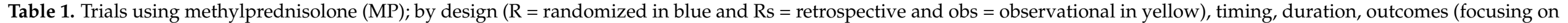
mortality data), and viral shedding.

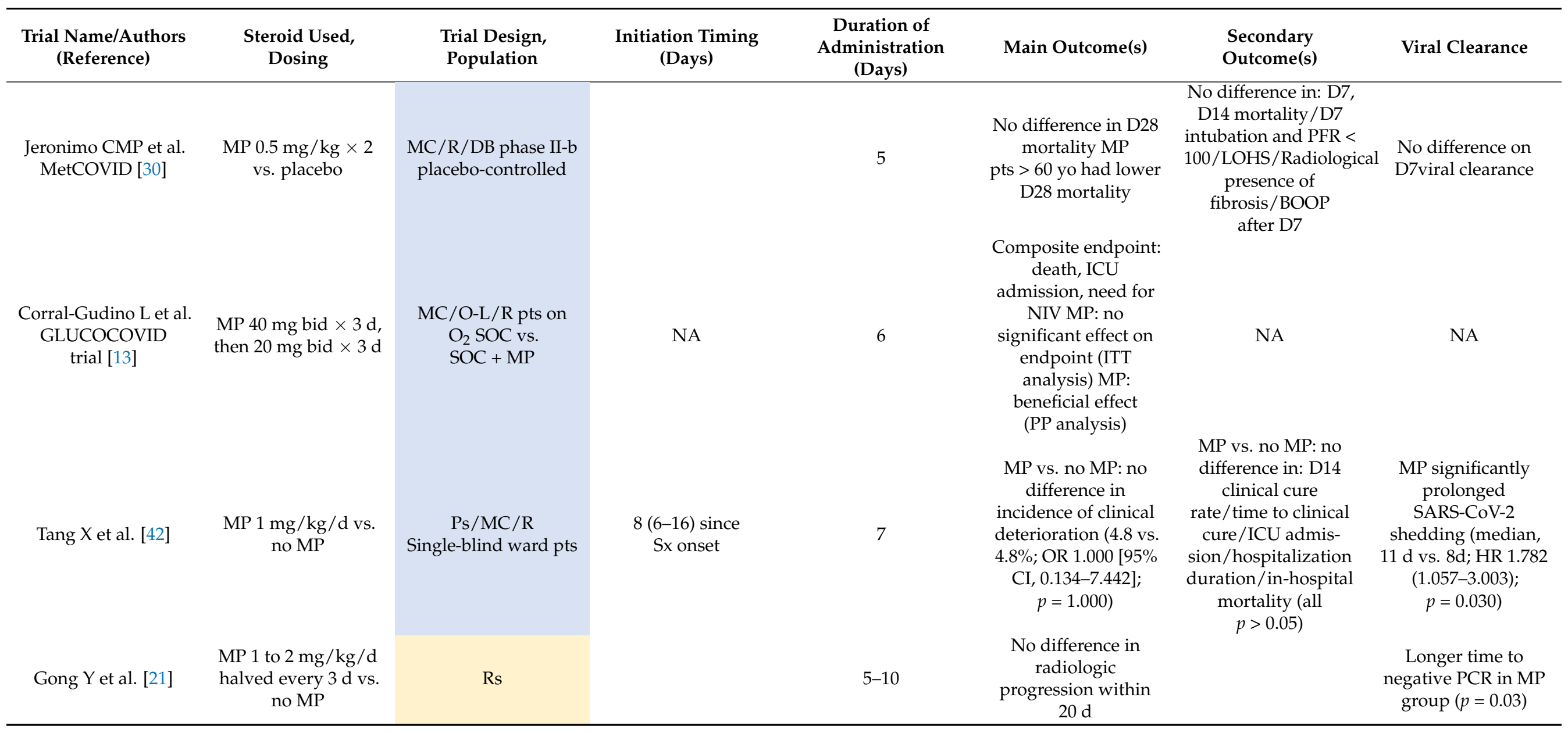


Table 1. Cont.

\begin{tabular}{|c|c|c|c|c|c|c|c|}
\hline $\begin{array}{l}\text { Trial Name/Authors } \\
\text { (Reference) }\end{array}$ & $\begin{array}{l}\text { Steroid Used, } \\
\text { Dosing }\end{array}$ & $\begin{array}{l}\text { Trial Design, } \\
\text { Population }\end{array}$ & $\begin{array}{l}\text { Initiation Timing } \\
\text { (Days) }\end{array}$ & $\begin{array}{l}\text { Duration of } \\
\text { Administration } \\
\text { (Days) }\end{array}$ & Main Outcome(s) & $\begin{array}{l}\text { Secondary } \\
\text { Outcome(s) }\end{array}$ & Viral Clearance \\
\hline Wang et al. [35] & $\mathrm{MP} 1$ to $2 \mathrm{mg} / \mathrm{kg} / \mathrm{d}$ & $\begin{array}{l}\text { Obs severe } \\
\text { COVID-19 pts }\end{array}$ & & $5-7$ & $\begin{array}{c}\text { MP: faster } \mathrm{SpO}_{2} \\
\text { improvement, less } \\
\text { likely to receive } \mathrm{MV} \\
(p=0.05), \text { faster } \downarrow \\
\text { CRP, IL-6 No } \\
\text { significant difference } \\
\text { in: mortality, } \downarrow \text { LOHS } \\
\text { and ICU LOS }\end{array}$ & & \\
\hline Papamanoli A et al. [43] & $\begin{array}{l}\text { MP median } 160 \mathrm{mg} \\
\quad(120-180) / \mathrm{d}\end{array}$ & $\begin{array}{l}\text { SC/Rs cohort HFNC } \\
>50 \%, \text { MP vs. no CS }\end{array}$ & $\begin{array}{l}10 \text { since } S x \text { onset, } 2 \\
\text { since admission, } 1 \\
\text { since HFNC } \\
\text { initiation }\end{array}$ & $\begin{array}{l}\text { Median: } 10 \text { incl } \\
\text { tapering }\end{array}$ & $\begin{array}{l}\text { MP: } 37 \% \text { lower risk } \\
\text { of death D28 } \\
(p=0.003) \text { and less } \\
\text { frequent MV } \\
(p=0.001) \\
\text { MP Mortality } 13.9 \%\end{array}$ & $\begin{array}{c}\text { No difference in } \\
\text { mortality between } \\
\text { groups }\end{array}$ & \\
\hline Fernandez-Cruz et al. [32] & $\begin{array}{l}\mathrm{MP} 1 \mathrm{mg} / \mathrm{kg} / \mathrm{d} \\
\text { or pulse }\end{array}$ & SC/Rs MP vs. no MP & 10 since Sx onset & NA & $\begin{array}{c}\text { vs. } 23.9 \% \text { no MP } \\
(\mathrm{HR}=0.5195 \% \mathrm{CI} \\
0.27-0.96, p=0.044) \\
\text { Dosing scheme not } \\
\text { associated with } \\
\text { mortality. }\end{array}$ & $\begin{array}{c}\text { Mortality in } \\
\text { moderate-severe } \\
\text { ARDS: MP } 26.2 \% \text { vs. } \\
60 \% \text { no CS, OR }=0.23 \\
(95 \% \text { CI, } 0.08-1.71)\end{array}$ & \\
\hline Zha L et al. [44] & MP 40-80 mg/day & $\begin{array}{l}\text { Obs / MC CS vs. } \\
\text { no CS }\end{array}$ & $\begin{array}{l}\text { within } 24 \mathrm{~h} \text { after } \\
\text { admission }\end{array}$ & 5 & $\begin{array}{l}\text { LOHS and Duration } \\
\text { of Sx: not associated } \\
\text { with CS }\end{array}$ & & $\begin{array}{l}\text { CS: no influence on } \\
\text { viral clearance }\end{array}$ \\
\hline $\begin{array}{l}\text { Li Y et al. [45], } \\
\text { Shangai cohort }\end{array}$ & $\begin{array}{c}\mathrm{MP} 0.75-1 \mathrm{mg} / \mathrm{kg} / \mathrm{d} \\
\times 3 \mathrm{~d} \text {, then } 20 \mathrm{mg} \\
\mathrm{MP} \times 3 \mathrm{~d} \text { vs. (no MP } \\
\text { and rescue CS) }\end{array}$ & $\mathrm{MC} / \mathrm{Obs} /$ & $\begin{array}{l}\text { Early (according to } \\
\text { LDH and } \\
\text { radiographic } \\
\text { progression) }\end{array}$ & $\leq 7$ & $\begin{array}{c}\downarrow \text { MV need in early } \\
\text { MP }(p=0.037)\end{array}$ & & $\begin{array}{l}\text { No difference in viral } \\
\text { clearance time }\end{array}$ \\
\hline Ma Q et al. [38] & $\begin{array}{c}\text { MP } 40-80 \mathrm{mg} / \mathrm{d} \text { vs. } \\
\text { no CS }\end{array}$ & $\begin{array}{l}\text { MC/Rs cohort severe } \\
\text { and critically ill pts }\end{array}$ & & & $\begin{array}{l}\text { No difference: } \\
\text { Mortality, LOHS } \\
\text { CS group: } \\
\downarrow \text { Sx duration }\end{array}$ & & $\begin{array}{l}\text { No difference in viral } \\
\text { clearance time }\end{array}$ \\
\hline
\end{tabular}


Table 1. Cont

\begin{tabular}{|c|c|c|c|c|c|c|c|}
\hline $\begin{array}{l}\text { Trial Name/Authors } \\
\text { (Reference) }\end{array}$ & $\begin{array}{l}\text { Steroid Used, } \\
\text { Dosing }\end{array}$ & $\begin{array}{l}\text { Trial Design, } \\
\text { Population }\end{array}$ & $\begin{array}{l}\text { Initiation Timing } \\
\text { (Days) }\end{array}$ & $\begin{array}{c}\text { Duration of } \\
\text { Administration } \\
\text { (Days) }\end{array}$ & Main Outcome(s) & $\begin{array}{l}\text { Secondary } \\
\text { Outcome(s) }\end{array}$ & Viral Clearance \\
\hline Salton F et al. [22] & $\begin{array}{c}\text { MP } 80 \mathrm{mg} \text { loading } \\
\text { dose, then } \\
80 \mathrm{mg} / \text { day cont } \\
\text { infusion }\end{array}$ & $\begin{array}{c}\text { MC/Obs severe } \\
\text { COVID-19 MP vs. } \\
\text { no MP }\end{array}$ & & Min 8 & $\begin{array}{c}\text { Composite } \\
\text { endpoint:ICU } \\
\text { referral/ intubation } \\
\text { need/ D28 death: } \\
\text { significantly } \downarrow \\
\text { compared with the } \\
\text { control group: aHR, } \\
0.41\end{array}$ & MV free d $\triangle \mathrm{CRP}$ & Not affected \\
\hline Yuan M et al. [46] & $\begin{array}{l}\text { MP max dose } \\
52.5 \mathrm{mg}\end{array}$ & $\begin{array}{l}\text { Rs nonsevere pts MP } \\
\text { vs. no MP }\end{array}$ & $\begin{array}{l}\text { Median } 8.3 \text { since } \\
\text { Sx onset }\end{array}$ & Median duration 10.8 & $\begin{array}{l}\text { Nonsevere pts on } \\
\text { CS:progressed to } \\
\text { severe disease, had } \uparrow \\
\text { LOHS and } \downarrow c \\
\text { duration of fever (not } \\
\text { statistically } \\
\text { significant difference } \\
\text { vs. non-CS pts) }\end{array}$ & & $\begin{array}{l}\text { Nonsevere pts on CS: } \\
\uparrow \text { duration of viral } \\
\text { shedding, (not } \\
\text { statistically } \\
\text { significant difference) }\end{array}$ \\
\hline
\end{tabular}




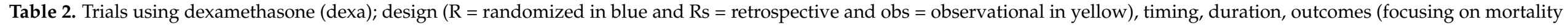
data), and viral shedding.

\begin{tabular}{|c|c|c|c|c|c|c|c|}
\hline $\begin{array}{l}\text { Trial Name/Authors } \\
\text { (Reference) }\end{array}$ & $\begin{array}{l}\text { Steroid Used, } \\
\text { Dosing }\end{array}$ & $\begin{array}{l}\text { Trial Design, } \\
\text { Population }\end{array}$ & Initiation Timing & $\begin{array}{c}\text { Duration of } \\
\text { Administration } \\
\text { (Days) }\end{array}$ & Main Outcome(s) & $\begin{array}{l}\text { Secondary } \\
\text { Outcome(s) }\end{array}$ & Viral Clearance \\
\hline $\begin{array}{l}\text { Tomazini BM et al. } \\
\text { CoDEX trial [27] }\end{array}$ & $\begin{array}{c}\text { dexa } 20 \mathrm{mg} \text { iv } \times 5 \mathrm{~d} \text {, } \\
\text { then } 10 \mathrm{mg} \\
\text { dexa } \times 5 \mathrm{~d} \text { or until } \\
\text { ICU discharge }\end{array}$ & $\begin{array}{c}\mathrm{MC} / \mathrm{R} / \mathrm{O}-\mathrm{L} \\
\text { moderate to severe } \\
\text { ARDS: SOC vs. } \\
\text { SOC + dexa }\end{array}$ & Not mentioned & $\leq 10$ & $\begin{array}{c}\text { Dexa group: mean } \\
\text { 6.6 ventilator-free d } \\
\text { (95\% CI, } 5.0-8.2) \text { vs. } \\
\text { SOC group: } 4.0 \\
\text { ventilator-free d (95\% } \\
\text { CI, } 2.9-5.4 \text { ), } \\
\text { (difference, } 2.26 ; 95 \% \\
\text { CI, } 0.2-4.38 ; p=0.04 \text { ). }\end{array}$ & $\begin{array}{l}\text { D28 no significant } \\
\text { difference in: } \\
\text { All-cause mortality } \\
\text { Clinical status ICU } \\
\text { free d MV } \\
\text { duration SOFA }\end{array}$ & NA \\
\hline RECOVERY trial [16] & $\begin{array}{c}\text { dexa } 6 \mathrm{mg} / \text { day pos } \\
\text { or iv }\end{array}$ & $\begin{array}{c}\text { Controlled/O-L CS } \\
\text { vs. SOC }\end{array}$ & NA & 10 & $\begin{array}{c}\text { D28 mortality: } 22.9 \% \\
\text { dexa vs. } 25.7 \% \text { SOC, } \\
\text { greater } \downarrow \text { in pts on } \\
\mathrm{MV}>\mathrm{O}_{2} \text { and if } \\
\text { initiation }>7 \mathrm{~d}\end{array}$ & $\begin{array}{l}\text { Time to discharge } \\
\text { Need for MV Need } \\
\text { for CRRT }\end{array}$ & NA \\
\hline
\end{tabular}

Table 3. Trials using hydrocortisone (HC); design ( $\mathrm{R}=$ randomized in blue), timing, duration, outcomes (focusing on mortality data), and viral shedding.

\begin{tabular}{|c|c|c|c|c|c|c|c|}
\hline $\begin{array}{l}\text { Trial Name/Authors } \\
\text { (Reference) }\end{array}$ & $\begin{array}{l}\text { Steroid Used, } \\
\text { Dosing }\end{array}$ & $\begin{array}{l}\text { Trial Design, } \\
\text { Population }\end{array}$ & Initiation Timing & $\begin{array}{c}\begin{array}{c}\text { Duration of } \\
\text { Administration } \\
\text { (Days) }\end{array} \\
\end{array}$ & Main Outcome(s) & $\begin{array}{l}\text { Secondary } \\
\text { Outcome(s) }\end{array}$ & Viral Clearance \\
\hline Dequin P-F et al. [28] & $\begin{array}{c}\text { HC Cont iv: } \\
200 \mathrm{mg} \times 7 \mathrm{~d} \text {, then } \\
100 \mathrm{mg} \times 4 \mathrm{~d} \text {, then } \\
50 \mathrm{mg} \times 3 \mathrm{~d}\end{array}$ & $\begin{array}{l}\mathrm{MC} / \mathrm{R} / \mathrm{DB} \text { critically } \\
\text { ill pts }\end{array}$ & & Total max 14 & $\begin{array}{l}\text { D21 Tx failure (death, } \\
\text { persistent MV, } \\
\text { HFNC): No } \\
\text { significant difference } \\
\text { between CS and } \\
\text { placebo } \\
\text { (under-powered, } \\
\text { stopped early) }\end{array}$ & $\begin{array}{c}\text { No significant } \\
\text { difference in: need } \\
\text { for intubation, } \\
\text { proning, ECMO, NO }\end{array}$ & \\
\hline Angus DC et al. [29] & $\begin{array}{c}\text { HC Fixed: } \\
50-100 \mathrm{mg} \times 4 \\
\text { Shock HC: } 50 \mathrm{mg} \times 4\end{array}$ & $\begin{array}{c}\text { O-L/R, severe } \\
\text { COVID-19 pts, fixed } \\
\text { dose HC vs. shock } \\
\text { dose HC vs. no HC }\end{array}$ & & 7 & $\begin{array}{l}\text { D21 organ-support } \\
\text { free ds: Probability of } \\
\text { superiority compared } \\
\text { to no CS: } 93 \% \text { in } \\
\text { fixed dose HC } 80 \% \text { in } \\
\text { shock dose HC }\end{array}$ & $\begin{array}{l}\text { Mortality rate: } 30 \% \\
\text { fixed dose } 26 \% \text { shock } \\
\text { dose } 33 \% \text { no CS }\end{array}$ & \\
\hline
\end{tabular}




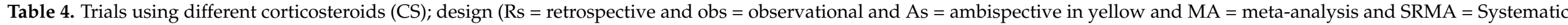
Review and Meta-analysis in orange), timing, duration, outcomes (focusing on mortality data), and viral shedding.

\begin{tabular}{|c|c|c|c|c|c|c|c|}
\hline $\begin{array}{l}\text { Trial Name/Authors } \\
\text { (Reference) }\end{array}$ & $\begin{array}{l}\text { Steroid Used, } \\
\text { Dosing }\end{array}$ & $\begin{array}{l}\text { Trial Design, } \\
\text { Population }\end{array}$ & Initiation Timing & $\begin{array}{c}\text { Duration of } \\
\text { Administration } \\
\text { (Days) }\end{array}$ & Main Outcomes & $\begin{array}{l}\text { Secondary } \\
\text { Outcome(s) }\end{array}$ & Viral Clearance \\
\hline Wu C et al. [14] & $\begin{array}{c}\text { Max dose: } 80 \text { mg MP } \\
\text { equiv (IQR = 40-80) } \\
\text { mg }\end{array}$ & $\mathrm{SC} / \mathrm{Rs} / \mathrm{Obs}$ & NA & $7(4-12)$ & $\begin{array}{c}\text { D-60 } \\
\text { in-hospital-mortality: } \\
\text { Significant } \downarrow \text { in CS } \\
(p=0.0160)\end{array}$ & NA & $\begin{array}{l}\text { CS not associated } \\
\text { with delayed } \\
\text { viral clearance }\end{array}$ \\
\hline Liu J et al. [18] & Not mentioned & Rs/Obs CS vs. no CS & & & $\begin{array}{c}\text { CS D28 mortality } \\
44.3 \% \text { vs. no CS } 31 \% \\
(p<0.001) \\
\text { Mortality in CS } \\
\text { group linked to HD } \\
\text { and early initiation } \\
\quad(<3 \text { d from } \\
\text { hospitalization })\end{array}$ & & $\begin{array}{c}\text { Delayed (SHR 1.59 CI } \\
95 \%, 1.17-2.15) \\
p=0.003\end{array}$ \\
\hline Li Y et al. [36] & $\begin{array}{l}\text { Median } 200 \mathrm{mg} / \mathrm{d} \\
\text { HC equiv (100-320.9) }\end{array}$ & $\begin{array}{l}\text { Rs/MC critically ill } \\
\text { pts CS vs. no CS }\end{array}$ & & $9(5-14)$ & $\begin{array}{l}\text { No significant } \\
\text { difference in } \\
\text { mortality }\end{array}$ & & $\begin{array}{l}\text { CS prolonged viral } \\
\text { shedding }\end{array}$ \\
\hline Lu X et al. [19] & $\begin{array}{c}\text { Different CS, } \\
\text { 100-800 mg/day HC } \\
\text { equiv }\end{array}$ & $\begin{array}{l}\text { SC/Rs, critically ill } \\
\text { pts, CS vs. no CS }\end{array}$ & & Median 8 (4-12) & $\begin{array}{c}\text { CS independent from } \\
\text { overall mortality. HD } \\
\text { CS: } \uparrow \text { mortality risk } \\
(p=0.003)\end{array}$ & NA & NA \\
\hline Li Q et al. [47] & $\begin{array}{c}5 \text { pts on pos } \\
\text { prednisone }(\mathrm{MP} \\
\text { equiv dose } 20 \mathrm{mg} / \mathrm{d}) \\
\text { and } 50 \text { pts on iv MP } \\
20-40 \mathrm{mg} / \mathrm{d}\end{array}$ & $\begin{array}{c}\text { Rs nonsevere pts } \\
\text { early LD CS vs. } \\
\text { no CS }\end{array}$ & $\begin{array}{l}\text { 1-5 d after hospital } \\
\text { admission }\end{array}$ & $\begin{array}{l}3 \text { (Oral prednisone) } \\
\text { 3-5 (iv MP) }\end{array}$ & $\begin{array}{c}\text { CS in nonsevere } \\
\text { COVID-19 } \\
\text { pneumonia: } \uparrow \text { risk of } \\
\text { progression to severe } \\
\text { disease, } \uparrow \text { use of } \\
\text { antibiotics, } \uparrow \\
\text { duration of fever, } \\
\uparrow \text { LOHS }\end{array}$ & & $\begin{array}{c}\text { CS in nonsevere } \\
\text { COVID-19 } \\
\text { pneumonia: prolongs } \\
\text { virus clearance time }\end{array}$ \\
\hline Ma Y et al. [48] & $\begin{array}{l}\text { MP equiv } 56.6 \mathrm{mg} \\
\text { median daily dose }\end{array}$ & $\begin{array}{c}\text { Rs } / \mathrm{MC} \text {, severe and } \\
\text { nonsevere } \\
\text { COVID-19 pts }\end{array}$ & & 5 median duration & $\begin{array}{c}\text { CS: } \uparrow \text { LOS in } \\
\text { nonsevere pts } \\
(p<0.05) \text { BUT no } \\
\text { significant } \uparrow \text { LOS of } \\
\text { severe pts }\end{array}$ & & $\begin{array}{l}\text { CS: } \uparrow \text { viral shedding } \\
\text { duration only in } \\
\text { nonsevere pts } \\
(p<0.05)\end{array}$ \\
\hline
\end{tabular}


Table 4. Cont.

\begin{tabular}{|c|c|c|c|c|c|c|c|}
\hline $\begin{array}{l}\text { Trial Name/Authors } \\
\text { (Reference) }\end{array}$ & $\begin{array}{l}\text { Steroid Used, } \\
\text { Dosing }\end{array}$ & $\begin{array}{l}\text { Trial Design, } \\
\text { Population }\end{array}$ & Initiation Timing & $\begin{array}{c}\text { Duration of } \\
\text { Administration } \\
\text { (Days) }\end{array}$ & Main Outcomes & $\begin{array}{l}\text { Secondary } \\
\text { Outcome(s) }\end{array}$ & Viral Clearance \\
\hline Li S et al. [49] & Not mentioned & 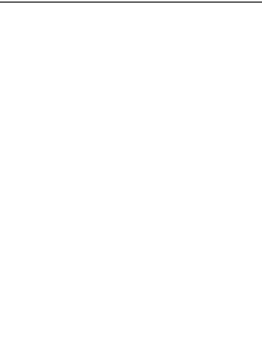 & Not mentioned & Not mentioned & $\begin{array}{l}\text { Assessment of risk } \\
\text { factors for long-term } \\
\text { (>30 d) positive } \\
\text { SARS-CoV-2 and } \\
\text { viral shedding }\end{array}$ & NA & $\begin{array}{c}\mathrm{HD}(80 \mathrm{mg} / \text { day; } \\
\text { aHR, } 0.67(95 \% \mathrm{CI}, \\
0.46-0.96) p=0.031) \\
\text { but not LD CS }(40 \\
\mathrm{mg} / \text { day; aHR, } 0.72 \\
(95 \% \mathrm{CI}, 0.48-1.08), \\
p=0.11) \text { potentially } \\
\text { delayed viral } \\
\text { shedding }\end{array}$ \\
\hline Shi D et al. [50] & & Rs/SC & & & $\begin{array}{l}\text { Factors associated } \\
\text { with prolonged viral } \\
\text { shedding } \\
\text { CS vs. no CS: no } \\
\text { significant difference }\end{array}$ & & $\begin{array}{l}\text { CS:not independent } \\
\text { factor of prolonged } \\
\text { viral shedding }\end{array}$ \\
\hline Hu Y et al. [37] & $\begin{array}{c}0.75-1 \mathrm{mg} / \mathrm{kg} / \mathrm{d} \\
\mathrm{MP} \text { equiv }\end{array}$ & Rs CS vs. no CS & $\begin{array}{c}\text { Median time since Sx } \\
\text { onset: } 7\end{array}$ & $6(\mathrm{IQR}, 4-8)$ & $\begin{array}{l}\text { in: imaging } \\
\text { progression, 90-day } \\
\text { mortality. Significant } \\
\text { difference in } \\
\text { lymphocytes } \\
\text { and CRP }\end{array}$ & & $\begin{array}{l}\text { CS vs. no CS: no } \\
\text { significant difference } \\
\text { in time to } \\
\text { negative PCR }\end{array}$ \\
\hline Keller MJ et al. [33] & CS vs. no CS & Obs incl children & $\begin{array}{l}\text { Within } 48 \mathrm{~h} \text { of } \\
\text { admission }\end{array}$ & & $\begin{array}{c}\text { CS: no effect on } \\
\text { mortality, BUT if } \\
\text { CRP }>20 \text {; significant } \\
\downarrow \text { risk of mortality or } \\
\text { MV [OR } 0.23,95 \% \text { CI, } \\
0.08-0.7] \text {. If CRP }<10 \text {; } \\
\text { significant } \uparrow \text { risk of } \\
\text { mortality or MV [OR } \\
2.64,95 \% \text { CI, } \\
1.39-5.03]\end{array}$ & & \\
\hline
\end{tabular}


Table 4. Cont.

\begin{tabular}{|c|c|c|c|c|c|c|c|}
\hline $\begin{array}{l}\text { Trial Name/Authors } \\
\text { (Reference) }\end{array}$ & $\begin{array}{l}\text { Steroid Used, } \\
\text { Dosing }\end{array}$ & $\begin{array}{l}\text { Trial Design, } \\
\text { Population }\end{array}$ & Initiation Timing & $\begin{array}{l}\text { Duration of } \\
\text { Administration } \\
\text { (Days) }\end{array}$ & Main Outcomes & $\begin{array}{l}\text { Secondary } \\
\text { Outcome(s) }\end{array}$ & Viral Clearance \\
\hline 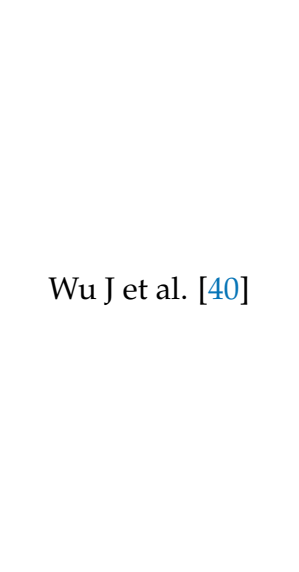 & $\begin{array}{l}\text { MP equiv dose } \\
40 \mathrm{mg} / \mathrm{d}\end{array}$ & $\begin{array}{l}\text { Rs severe and } \\
\text { critically ill pts }\end{array}$ & $24 \mathrm{~h}$ after Dx & Median 6 (3-10) & $\begin{array}{c}\text { CS independently } \\
\text { associated with } \uparrow \\
\text { in-hospital mortality } \\
\text { in severe COVID-19 } \\
\text { (HR = 1.43, 95\% CI: } \\
0.82-2.49, p=0.201 \text { in } \\
\text { IPTW; HR = 1.55, } \\
95 \% \text { CI: } 0.83-2.87, \\
p=0.166 \text { in PSM) } \\
\text { and critically-ill pts } \\
\text { (HR = 3.34, 95\% CI: } \\
\text { 1.84-6.05, } p<0.001 \text { in } \\
\text { IPTW; HR = 2.90, } \\
\text { 95\% CI: } 1.17-7.16, \\
p=0.021 \text { in PSM) }\end{array}$ & & \\
\hline Albani F et al. [39] & $\begin{array}{l}\text { Median dexa equiv } \\
\text { dose } 20 \mathrm{mg} / \text { day }\end{array}$ & Rs CS vs. no CS & & & $\begin{array}{l}\text { CS not associated } \\
\text { with } \\
\text { in-hospital mortality }\end{array}$ & CS: $\downarrow$ ICU admission & \\
\hline Fang X et al. [51] & $\begin{array}{c}\text { Median dose (HC } \\
\text { equiv) pos } \\
237.5 \mathrm{mg} / \text { iv } 250 \mathrm{mg} \\
\text { in general/severe pts }\end{array}$ & $\begin{array}{l}\text { Rs, pts of different } \\
\text { severity, CS vs. no CS }\end{array}$ & Not mentioned & $\begin{array}{l}\text { Median duration: } \\
7 / 4 \text { in } \\
\text { general/severe pts }\end{array}$ & 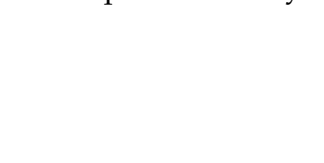 & & $\begin{array}{c}\text { CS:no significant } \\
\text { difference in viral } \\
\text { shedding irrespective } \\
\text { of severity }\end{array}$ \\
\hline Li X et al. [41] & $\begin{array}{l}\text { Median cumulative } \\
\text { dose equiv to } 200 \mathrm{mg} \\
\text { prednisone }\end{array}$ & As, CS vs. no CS & NA & Median duration: 4 & $\begin{array}{c}\text { severity on } \\
\text { admission, } \\
\text { complications, Tx, } \\
\text { and outcomes: HD } \\
\text { CS during } \\
\text { hospitalization (aHR, } \\
\text { 3.5; 95\%CI, 1.8-6.9] } \\
\text { was significant risk } \\
\text { factor associated } \\
\text { with death in } \\
\text { severe COVID-19 }\end{array}$ & NA & NA \\
\hline
\end{tabular}


Table 4. Cont.

\begin{tabular}{|c|c|c|c|c|c|c|c|}
\hline $\begin{array}{l}\text { Trial Name/Authors } \\
\text { (Reference) }\end{array}$ & $\begin{array}{l}\text { Steroid Used, } \\
\text { Dosing }\end{array}$ & $\begin{array}{l}\text { Trial Design, } \\
\text { Population }\end{array}$ & Initiation Timing & $\begin{array}{c}\text { Duration of } \\
\text { Administration } \\
\text { (Days) }\end{array}$ & Main Outcomes & $\begin{array}{l}\text { Secondary } \\
\text { Outcome(s) }\end{array}$ & Viral Clearance \\
\hline Sarkar S et al. [20] & 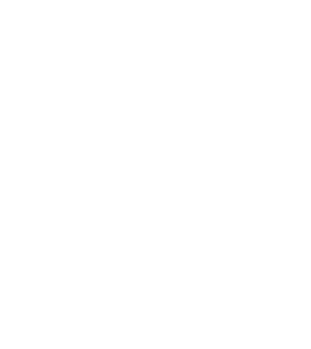 & $\begin{array}{l}\text { SRMA ( } 2 \text { RCTs and } \\
10 \text { cohorts) }\end{array}$ & & & $\begin{array}{c}\text { CS: } \uparrow \text { mortality } \\
(\mathrm{OR}=1.94,95 \% \mathrm{CI}: \\
\left.1.11-3.4, I^{2}=96 \%\right), \\
\text { irrespective of } \\
\text { severity or dosage } \\
\text { and } \uparrow \mathrm{LOHS} \\
(\mathrm{MD}=1.18 \mathrm{~d}, 95 \% \mathrm{CI} \text { : } \\
-1.28 \text { to } 3.64 \\
\left.I^{2}=93 \%\right)\end{array}$ & & $\begin{array}{c}\text { CS may prolong viral } \\
\text { shedding } \\
\begin{array}{c}(\mathrm{MD}=1.42 \mathrm{~d}, 95 \% \mathrm{CI} \text { : } \\
-0.52 \text { to } 3.37 \\
\left.I^{2}=0 \%\right)\end{array}\end{array}$ \\
\hline $\begin{array}{l}\text { Sterne JAC et al. } \\
\text { REACT [23] }\end{array}$ & $\begin{array}{c}\text { Different CS in } \\
\text { different schemes }\end{array}$ & $\begin{array}{c}\text { Ps/MA (7 RCTs) CS } \\
\text { vs. SOC }\end{array}$ & & & $\begin{array}{c}\text { CS: } \downarrow \text { all-cause } \\
\text { D28-mortality: dexa } \\
\text { vs. SOC OR } 0.64 \text { [95\% } \\
\text { CI, } 0.5-0.82 . p<0.01] \\
\text { HC vs. SOC OR 0.69 } \\
\text { [95\% CI, } 0.53-0.82 \\
p=0.13], \text { MP vs. } \\
\text { SOC OR } 0.91 \\
\text { [0.29-2.87, } p=0.87]\end{array}$ & $\begin{array}{l}\text { No difference in } \\
\text { serious AEs }\end{array}$ & \\
\hline Pasin L et al. [24] & & $\begin{array}{l}\text { SRMA ( } 5 \text { RCT)CS vs. } \\
\text { any other Tx }\end{array}$ & & & $\begin{array}{c}\text { CS: } \downarrow \text { Mortality rate } \\
(26 \% \text { in CS vs. } 28 \% \text { in } \\
\text { no CS, RR }=0.89, \mathrm{CI} \\
95 \%, 0.82-0.96, \\
p=0.003) \mathrm{CS}: \uparrow \\
\text { mortality in pts on no } \\
\mathrm{O}_{2}\end{array}$ & $\begin{array}{l}\text { Significant } \downarrow \text { of MV } \\
\text { risk in CS group }\end{array}$ & \\
\hline Van Paassen [25] & Diverse CS strategies & $\begin{array}{l}\text { SRMA (RCTs } \\
\text { and Obs) }\end{array}$ & & & $\begin{array}{l}\text { CS are beneficial in } \\
\text { short-term mortality }\end{array}$ & CS: $\downarrow$ MV need & $\begin{array}{l}\text { CS: not clear effect on } \\
\text { viral clearance }\end{array}$ \\
\hline
\end{tabular}


Table 4. Cont.

\begin{tabular}{|c|c|c|c|c|c|c|c|}
\hline $\begin{array}{l}\text { Trial Name/Authors } \\
\text { (Reference) }\end{array}$ & $\begin{array}{l}\text { Steroid Used, } \\
\text { Dosing }\end{array}$ & $\begin{array}{l}\text { Trial Design, } \\
\text { Population }\end{array}$ & Initiation Timing & $\begin{array}{c}\text { Duration of } \\
\text { Administration } \\
\text { (Days) }\end{array}$ & Main Outcomes & $\begin{array}{l}\text { Secondary } \\
\text { Outcome(s) }\end{array}$ & Viral Clearance \\
\hline Cano EJ et al. [26] & $\begin{array}{l}\text { Different CS in } \\
\text { different doses }\end{array}$ & SRMA & & & $\begin{array}{c}\text { Mortality benefit in } \\
\text { CS group in severe } \\
\text { COVID-19: OR, } 0.65 \text {; } \\
95 \% \text { CI, } 0.51-0.83 \text {, } \\
p=0.0006 . \text { No } \\
\text { benefit or harmful } \\
\text { effect among HD and } \\
\text { LD CS }\end{array}$ & & $\begin{array}{c}\text { LD CS no significant } \\
\text { effect on } \\
\text { viral shedding }\end{array}$ \\
\hline
\end{tabular}

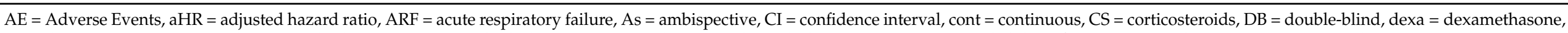

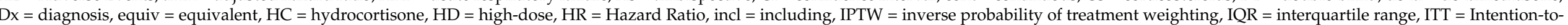

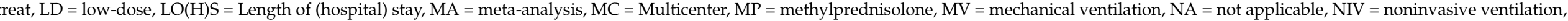

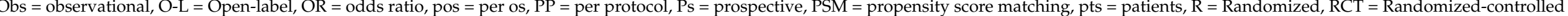

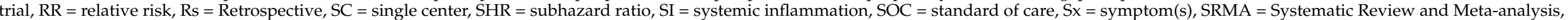
$\mathrm{Tx}=$ treatment, $\mathrm{vs} .=$ versus, yo $=$ years old, and $\Delta=$ change 


\section{Dexamethasone in COVID-19: Mode of Action}

Corticosteroids are known to temper down the host inflammatory response in the lungs, which may lead to acute lung injury and ARDS [52]. They exert their anti-inflammatory effects by binding to their receptor, the glucocorticoid receptor-GR. GR is a ligand-activated transcription factor whose signaling plays a key role in the modulation of numerous biological functions of the immune cells. Upon ligand binding, GR translocates to the nucleus, where it can enhance transcription by binding to glucocorticoid response elements (GREs). On the other hand, GR, when tethering directly to negative glucocorticoid response elements (nGREs) or GRE half-sites or by binding to transcription factors such as NF- $\mathrm{kB}$, may repress the expression of several genes [53]. Thus, it is evident that the corticosteroid treatment is a double-edged sword, which may induce or inhibit inflammatory cell activity. Several studies have shown that corticosteroids may inhibit T-lymphocyte immunity, an important antiviral mechanism, resulting in persistent viral replication and a delay in viral clearance. At the same time, the suppression of proinflammatory cytokines such as TNF, interleukins, and other genes, such as cyclooxygenase- 2 and inducible nitric oxide synthase (iNOS), and the inhibition of the neutrophils, macrophages, and lymphocytes inflammatory activity are documented as effects of corticosteroid use [54].

Dexamethasone has both anti-inflammatory and immunosuppressive effects. Specifically, when binding to GR, it initiates a cascade of immune cell responses that lead to the suppression of proinflammatory cytokines, such as IL-1, IL-6, IL-8, TNF, and IFN- $\gamma$, by inhibiting gene transcription [54]. In the case of SARS-CoV-2 infection, those are the produced proinflammatory cytokines that result in local tissue inflammation and in the socalled "cytokine storm" [55]. Furthermore, dexamethasone exerts anti-inflammatory effects by inhibiting macrophage activation [56], neutrophil's adhesion to endothelial cells, and the release of lysosomal enzymes, preventing chemotaxis at the site of inflammation. Finally, it increases IL-10 gene expression, thus exhibiting further anti-inflammatory effects [57].

Another important function of dexamethasone is its implication in the process of the resolution of inflammation by inducing the D-series pro-resolving lipid mediator pathway via the formation of protectins D1 and DX7 and of 17S-dihydroxydocosahexaenoic acid (17S-HDHA) [58]. These agents have documented roles in driving the resolution of inflammation by regulating the termination of proinflammatory responses, the removal of inflammatory cells, and the tissue repair mechanisms [59]. Finally, certain lipid mediators have been shown to diminish pathologic thrombosis and NETosis, decrease the levels of procoagulant factors and fibrinogen, enhance the removal of clots, and increase the anticoagulant factors [60]. These functions are of high importance, since the thrombotic pathways are central in the pathology of COVID-19 infection.

Overall, in critical COVID-19 patients, glucocorticoid therapy exerts several functions, such as effective homeostatic corrections and consequent improvement in the critical illnessrelated corticosteroid insufficiency (CIRCI), control of inflammation, and stabilization of cardiovascular and metabolic functions. Furthermore, it induces increased mitochondrial biogenesis, corrects the content and functions of the mitochondria, and decreases the devastating tissue oxidation that leads to multiple tissue and organ dysfunctions [61].

\section{Dexamethasone in COVID-19: Clinical Considerations}

Starting with the main results of the RECOVERY trial, the most robust until now, that gave dexamethasone a central role in the treatment of COVID-19, dexamethasone at a dose of $6 \mathrm{mg}$ per day for ten days was effective at reducing the mortality rate in both ventilated and oxygenated patients by one-third and one-fifth, respectively, compared to the usual care alone [16].

However, several questions relative to corticosteroid therapy arose:

1. Why use dexamethasone instead of other corticosteroids?

2. When to start corticosteroids?

3. At what dose and for how long?

4. Do they prolong viral shedding? 
5. How safe are corticosteroids in the treatment of severely affected COVID-19 patients?

6. What is the role of inhaled corticosteroids in preventing or treating COVID-19 patients?

7. Why use dexamethasone instead of other corticosteroids?

Pharmacologically, dexamethasone has a more advantageous pharmacokinetic/pharmacodynamic (PK/PD) profile. Dexamethasone is a long-acting synthetic corticosteroid with systemic effects and is almost 25 times more potent than other synthetic corticosteroids, as depicted by the equivalent steroid doses (40-mg hydrocortisone:10-mg prednisolone:8-mg methylprednisolone:1.5-mg dexamethasone) [62].

Dexamethasone's higher potency is explained by its higher affinity for the glucocorticoid receptor compared to other steroids, leading to a more profound genomic and metagenomic activity [62-64] and consequent greater inhibition of the proinflammatory pathways. Additionally, it possesses minimal mineral corticoid activity, limiting the undesired retention of the fluid and sodium. On the PK side, dexamethasone has a longer half-life of 36-72 h, allowing for once-daily dosing [65].

\subsection{When to Start Corticosteroids?}

The time of corticosteroid treatment initiation is of great importance in order to have favorable outcomes. Siddiqi and Mehra [66] suggested three escalating phases of COVID19 disease progression, with associated signs, symptoms, and potential phase-specific treatments: the early infection phase, the pulmonary phase, and the hyperinflammation phase, in which anti-inflammatory treatments (such as corticosteroids) are recommended as beneficial. Indeed, in the RECOVERY trial [16], a clear benefit was shown in the patients who were treated with dexamethasone for more than 7 days after symptom onset, when inflammatory lung damage was likely to be more common, and not among those with more recent symptom onsets. It is evident that randomized controlled trials are needed in order to clarify the right timing for the initiation of a corticosteroid treatment course.

\subsection{At What Dose and for How Long?}

Another consideration is whether "one size fits all" and how effective dexamethasone is in the dose of $6 \mathrm{mg}$ /day for ten days in all COVID-19 patients with respiratory failure, irrespectively of them developing ARDS or not. This daily dose is considered low, with few adverse events [39], as opposed to the 20-40 mg needed daily for hematologic malignancies, autoimmune diseases, or shock.

In an early single-center observational study in Wuhan [61], there was a lower risk of death in the patients who received low-dose corticosteroids ( $<1 \mathrm{mg} / \mathrm{kg} /$ day) or no corticosteroids at all compared to high-dose regimens, but the difference was not statistically significant.

In the CoDEX randomized trial in patients with COVID-19 with moderate-to-severe ARDS, the dose of dexamethasone administered (20 mg of dexamethasone intravenously daily for 5 days and $10 \mathrm{mg}$ of dexamethasone daily for 5 days or until ICU discharge) [27] was higher than that used in the RECOVERY trial. The selection of this higher dose was based on the design of a previous study [67] in patients with non-COVID-19 ARDS who were treated with dexamethasone (or equivalent) in the dose of $30 \mathrm{mg} /$ day. Eventually, a statistically significant increase in the number of ventilator-free days (days alive and free of mechanical ventilation) was shown over 28 days, with a good safety profile [27].

Furthermore, Papamanoli et al. [43] showed that, in nonintubated patients with severe COVID-19 pneumonia, higher doses of methylprednisolone (160 mg for a median duration of approximately 10 days) were associated with a lower risk for mechanical ventilation or death $(37 \%)$ and without consequent adverse effects. Interestingly, among the intubated patients, those that were treated with corticosteroids had more ventilator-free days and shorter length of ICU stays compared to the patients not receiving corticosteroids.

Fernandez-Cruz et al. [32] showed lower in-hospital mortalities in patients with SARSCoV-2 pneumonia treated with corticosteroids, no matter if they received an initial regimen of $1 \mathrm{mg} / \mathrm{kg} /$ day of methylprednisolone or with corticosteroid pulses. 
A more recent review and meta-analysis of 35 studies by Cano et al. [26] depicted the high heterogeneity of the practices in dosing steroids; in $74.2 \%$ of the studies, steroids were given in low doses, in $11.4 \%$, in high or pulse doses, and in $5.6 \%$, a mixed regimen was used. The meta-analysis failed to prove a beneficial or harmful effect of either dosing scheme.

To complicate the dosing dilemmas further, the published data showed that serum albumin plasma levels, competing drugs, and albumin glycation are important clinical variables influencing the effectiveness of dexamethasone in treating COVID-19 patients [68]. Each one of these factors decreases the binding capacity of albumin, complicating the transport capacity of dexamethasone and resulting in a shorter half-life of the drug and potential toxicity at its peak concentration. It might be appropriate to modify the dose of dexamethasone according to the albumin levels, patient's weight, and/or plasma levels in order to achieve the therapeutic levels and to avoid toxicity [69].

From a pathophysiology point of view, as Chrousos and Meduri concluded, corticosteroid administration in severe COVID-19 should start early, before the irreversible exhaustion of homeostatic reserves, with large doses to saturate the ubiquitous glucocorticoid receptors, so that the maximum effect is attained [70,71]. Following precision medicine, the dosing of corticosteroids should be tailored to each patients' unique manifestations, as Gogali et al. explained [72]. From the evidence-based medicine side, though, it is evident that the optimal corticosteroid dosing and duration of treatment still need clarification, especially in critically ill COVID-19 patients with ARDS. Towards this direction, the results of currently undergoing trials like "HIGHLOWDEXA" [20], assessing the efficacy of high doses of dexamethasone $(20 \mathrm{mg} /$ day for 5 days and then $10 \mathrm{mg} /$ day for 5 days $) \mathrm{vs}$. low doses of dexamethasone ( $6 \mathrm{mg} /$ day for 10 days) in patients with respiratory failure might shed more light on the therapeutic algorithms of severe COVID-19.

\subsection{Do Corticosteroids Prolong Viral Shedding?}

An analysis of the retrospective observational studies from the first pandemic wave showed results associating corticosteroids with immune suppression, an increased viral load, delayed clearance from the body, and increased mortality [21,22]. The early administration of corticosteroids in non-severely ill patients may be deleterious due to an increase of viral shedding or a delay in viral clearance [46]. Prolonged viral shedding has been supported by several retrospective studies [14,36]. Notably, nonsevere COVID-19 pneumonia patients who received early corticosteroid treatment had a more prolonged viral shedding compared to patients of similar severity who did not receive corticosteroids, as was shown in two cohorts $[47,48]$ and one randomized study [42]. A recent review and meta-analysis of 15 studies examining, among others, the SARS-CoV-2 clearance concluded a delay in viral clearance in patients receiving corticosteroids compared with patients who did not receive corticosteroids but failed to prove a statistical significance [20]. Importantly, there are implications that viral shedding prolongation follows a dose-dependent scheme of corticosteroids [49]. However, this theory was not confirmed in the study of Fang et al. [51], who used a low dose of corticosteroids in patients with COVID-19; there was no significant difference in the duration of viral shedding between patients receiving and patients not receiving corticosteroids, irrespective of the severity of the disease. Accordingly, no significant difference in the viral clearance was shown in other studies [22,30,37,38,45]. Two retrospective studies by $\mathrm{Xu}, \mathrm{K}$. and Shi, D. [73,74] concluded that corticosteroids were not independent predictors of prolonged viral shedding as opposed to the male sex, lymphocytopenia, APACHE score, and IVIG treatment.

To sum up, there is no clear conclusion as to whether corticosteroids delay the SARS$\mathrm{CoV}-2$ clearance, and more importantly, there is no certainty about the clinical significance of this.

\subsection{How Safe Are Corticosteroids in the Treatment of Severely Affected COVID-19 Patients?}

The long-term use of corticosteroids has well-established adverse effects. The shortterm use of steroids, although frequent in the pre-pandemic era, was only recently exam- 
ined for its potential adverse effects. Two large population-based studies in adults, an American [50] and a Chinese [75] one, underline the increased risk of complications in the outpatient setting. Waljee et al. [50] concluded that, within 30 days of steroid initiation, there was a two to five-fold increase in the incidence rates of fractures, venous thromboembolism, and admission for sepsis, in that order of frequency, in steroid users 18-64 years of age compared to non-users. Yao et al. [75] found a significant increase in gastrointestinal bleeding, sepsis, and heart failure in the respective Chinese population.

Currently the recommendations on corticosteroid use in COVID-19 concern severely ill inpatients requiring $\mathrm{O}_{2}$ or mechanical ventilation and definitely not outpatients. Is this sicker population threatened by the same harms of short-term corticosteroids use as the general population? The existing literature on COVID-19, although abundant, is not centered on adverse events.

Certain studies concluded that there were no significant differences in serious adverse events between corticosteroid and the standard-of-care groups [24,27,37,42,45,46], while others pointed to a greater probability of myocardial or liver injury, shock [21], and agitation [23] in corticosteroid-treated COVID-19 patients.

Supporting the safety of corticosteroids, the RECOVERY trial [16] reported a similar incidence of new cardiac arrhythmia in the dexamethasone group and the usual care group. In a total of 2104 patients, there were four reports of serious adverse reactions that were deemed by the investigators to be related to dexamethasone: two of hyperglycemia, one of gastrointestinal hemorrhage, and one of psychosis (all recognized adverse effects of corticosteroids).

In the CAPE COVID trial [28], which was stopped early after the publication of the results from the RECOVERY trial, the administration of a low dose hydrocortisone in 148 patients was followed by three serious events: one was cerebral vasculitis, attributed to the SARS-CoV-2 itself, the second was an episode of pulmonary embolism with cardiac arrest, which was considered single and unrelated to steroids, and the third event was an intrabdominal hemorrhage related to anticoagulation for pulmonary embolism.

In REMAP-CAP [29], the only adverse events that were considered relevant to the corticosteroid treatment were one event of neuromyopathy and one event of fungemia.

The recently published results of the OUTCOMEREA network [76] showed that COVID-19 critically ill patients have a higher risk for bloodstream infections (BSI) than their non-COVID-19 counterparts after 7 days of ICU stay, but this negative event was associated with the use of anti-IL-1 and anti-IL- 6 and not to corticosteroids. Similarly, no difference in BSI incidence was detected in the MetCOVID randomized trial [30] or the retrospective study by Papamanoli et al. [43].

On the contrary, Giacobbe et al. [77] in their retrospective single-center study, found a higher BSI risk for corticosteroid-treated patients (csHR 3.95, 95\% CI 1.2-13.03) than those receiving only tocilizumab (csHR $1.07,95 \%$ CI 0.38-3.04), the risk being even higher with their combination (csHR 10.69, 95\% CI 2.71-42.17).

The clinical research points towards an association between corticosteroid use and secondary infections. More secondary infections with sepsis have been recorded [26,36], but the difference was not always significant [13]. The indirect evidence on increased secondary infections may come from the increased antibiotic use in corticosteroid-treated patients, as two retrospective studies $[47,48]$ and one systematic review and meta-analyses [26] have shown.

The literature is more extensive on fungal infections in COVID-19 patients. Corticosteroid treatment is a well-known risk factor for invasive mycoses [78]. An excellent review of retrospective studies from China and Europe reported a $20-35 \%$ incidence of COVID-19-associated pulmonary aspergillosis (CAPA) [79] A case report of mucormycosis following the treatment with dexamethasone was reported in a 44-year-old diabetic woman [80] raising concerns about the duration and dosing of the corticosteroid treatment in diabetic COVID-19 patients. Hyperglycemia, which led to increased doses of insulin, was 
mentioned in most studies $[13,23,30,42]$ as an adverse event of the corticosteroid treatment as expected, but it was not severe [27].

Reviewing the literature concerning the adverse events of corticosteroid treatment in COVID-19 patients, we underline a significant deficit, as safety is not among the primary outcomes of most studies. This is not a surprise, because corticosteroids are used extensively, and physicians are very familiar with their use. Additionally, some of the main adverse effects of corticosteroids (i.e., VTE, secondary infections and GI hemorrhage) are the main COVID-19 complications or harms from other necessary treatments (i.e., anticoagulation), and perhaps, it is difficult to discriminate the proportional contribution of the virus or the steroids.

Targeting a safe treatment alternative to systemic corticosteroids, inhaled corticosteroids (ICS) have been proposed. There is a cumulative experience of ICS in chronic airways diseases like asthma and COPD, linking their use to changes in the microbiome and, finally, to the increased frequency of upper and lower respiratory tract infections [81,82]. However, an association of ICS with the susceptibility to viral infections is lacking. Instead, a paradoxical protection against viral infections has risen $[83,84]$. Ciclesonide seems to block SARS-CoV-2 replication in vitro, and in addition, it impedes its cytopathogenicity $[85,86]$. Early-stage COVID-19 treatment with inhaled corticosteroids might inhibit the progression of SARS-CoV-2 infection to COVID-19. This was shown in a small study of COVID-19 patients on oxygen (not mechanically ventilated) who improved after the treatment with inhaled ciclesonide [87] Similarly, there was in vitro evidence of budesonide's direct antiviral and anti-inflammatory properties [88]. In the recent open-label, in parallel groups, phase 2 randomized control trial in mild outpatient COVID-19 patients that received inhaled budesonide vs. the usual care, a 91\% reduction in the relative risk for COVID-19-related urgent care or hospitalization was shown in the budesonide-treated patients [89].

Patients with chronic lung disease, often on long-term ICS, form a special subcategory of COVID-19 patients. A systematic review of the patients with coronavirus acute respiratory infections (MERS, SARS and COVID-19) by Halpin et al. [90] did not reach a clear-cut conclusion as to whether premorbid use or the continuous administration of ICS is a benefit. Currently, there is a suggestion against the withdrawal of chronically used ICS; asthma and COPD patients receiving ICS are advised to carry on with their treatments [91,92]. Table 5 summarizes the commonest reported adverse events. 
Table 5. Trials and corticosteroid (CS)-related adverse effects (randomized trials in blue, retrospective/observational trials in yellow, and meta-analysis in orange).

\begin{tabular}{|c|c|c|c|c|c|c|c|c|c|}
\hline Trial Name & $\begin{array}{l}\text { Steroid Used, } \\
\text { Dosing }\end{array}$ & $\begin{array}{l}\text { Initiation } \\
\text { (Days) }\end{array}$ & $\begin{array}{l}\text { Duration } \\
\text { (Days) }\end{array}$ & Hyperglycemia & GI & CNS & CVS & $\begin{array}{l}\text { Secondary } \\
\text { Infections }\end{array}$ & Other \\
\hline $\begin{array}{l}\text { Jeronimo CMP } \\
\text { et al. } \\
\text { MetCOVID [30] }\end{array}$ & $\begin{array}{l}\text { MP } 0.5 \mathrm{mg} / \mathrm{kg} \\
\text { bid vs. placebo }\end{array}$ & & 5 & $\begin{array}{l}\text { MP group: } \\
\uparrow \text { insulin }\end{array}$ & & & & $\begin{array}{l}\text { No difference in } \\
\text { BC positivity }\end{array}$ & \\
\hline $\begin{array}{l}\text { Corral-Cudino } \\
\text { et al., GLUCO- } \\
\text { COVID [13] }\end{array}$ & $\begin{array}{c}\text { MP } 40 \mathrm{mg} \\
\text { bid } \times 3 \mathrm{~d} \text {, then } \\
20 \mathrm{mg} \text { bid } \times 3 \mathrm{~d}\end{array}$ & $\begin{array}{l}\text { Min } 7 \text { after } \\
\text { Sx onset }\end{array}$ & 6 & $\begin{array}{l}\text { MP: } \uparrow \text { Glu } \\
(p=0.015)\end{array}$ & & & & $\begin{array}{c}\text { MP: } \uparrow \\
\text { Secondary } \\
\text { infections } \\
(p=0.637)\end{array}$ & \\
\hline Tang X et al. [42] & $\begin{array}{c}1 \mathrm{mg} / \mathrm{kg} / \mathrm{d} \mathrm{MP} \\
\text { vs. no MP }\end{array}$ & $\begin{array}{l}\text { Median time } 8 \\
(6-16) \text { after Sx } \\
\text { onset }\end{array}$ & 7 & $\begin{array}{l}\text { no MP: } \uparrow \text { Glu } \\
\quad(p=0.313)\end{array}$ & $\begin{array}{l}\text { Either group: } \\
\text { No stress } \\
\text { ulcers/GI bleed }\end{array}$ & $\begin{array}{l}\text { Either group: } \\
\text { No delirium }\end{array}$ & & $\begin{array}{l}\text { MP: } \uparrow \text { VAP } \\
(p=0.557)\end{array}$ & \\
\hline $\begin{array}{l}\text { Papamanoli A } \\
\text { et al. [43] }\end{array}$ & $\begin{array}{l}\text { Median daily } \\
160 \mathrm{mg} \text { MP } \\
(120-180)\end{array}$ & $\begin{array}{l}10 \text { from Sx onset, } \\
2 \text { from } \\
\text { admission, } 1 \\
\text { from HFNC } \\
\text { initiation }\end{array}$ & $\begin{array}{l}\text { Median: } 10 \text { incl } \\
\text { tapering }\end{array}$ & & $\begin{array}{l}\text { GI bleed: no } \\
\text { difference }\end{array}$ & & & $\begin{array}{l}\text { Bacteremia, } \\
\text { HAP/VAP: } \\
\text { No difference }\end{array}$ & \\
\hline Salton F et al. [22] & $\begin{array}{l}80 \mathrm{mg} \text { MP } \\
\text { loading dose, } \\
\text { then } 80 \mathrm{mg} / \text { day } \\
\text { cont infusion }\end{array}$ & & Min 8 & MP: $\uparrow$ Glu & & $\begin{array}{l}\text { MP: Mild } \\
\text { agitation more } \\
\text { common }\end{array}$ & & & \\
\hline Yuan M et al. [46] & $\begin{array}{l}\text { MP max dose } \\
52.5 \mathrm{mg} \\
\text { nonsevere pts }\end{array}$ & $\begin{array}{l}\text { Median } 8.3 \text { from } \\
\text { Sx onset }\end{array}$ & $\begin{array}{c}\text { Median } \\
\text { duration } 10.8\end{array}$ & & & & & $\begin{array}{l}\text { CS vs. no CS: } \\
\text { No significant } \\
\text { difference in } \\
\text { secondary } \\
\text { infections }\end{array}$ & \\
\hline $\begin{array}{c}\text { RECOVERY trial } \\
{[16]}\end{array}$ & $\begin{array}{c}\text { dexa } 6 \mathrm{mg} / \text { day } \\
\text { pos or iv } \\
20 \mathrm{mg} \text { dexa }\end{array}$ & & & $2 / 2104$ pts & $\begin{array}{l}\text { GI bleed: } \\
\text { 1/2104 pts }\end{array}$ & $\begin{array}{l}\text { Psychosis: } \\
1 / 2104\end{array}$ & & & \\
\hline $\begin{array}{l}\text { Tomazini BM et al. } \\
\text { CoDEX trial [27] }\end{array}$ & $\begin{array}{l}\text { iv } \times 5 \mathrm{~d} \text {, then } \\
10 \mathrm{mg} \\
\text { dexa } \times 5 \mathrm{~d} \text { or } \\
\text { until ICU } \\
\text { discharge }\end{array}$ & & $\leq 10$ & $\begin{array}{c}\text { Insulin need: } \\
\text { Dexa: } 31.1 \% \\
\text { vs. SOC } 28.3 \%\end{array}$ & & & & $\begin{array}{l}\text { Dexa } 21.9 \% \text { vs. } \\
\text { SOC: } 29.1 \%\end{array}$ & $\begin{array}{c}\text { Other serious: } \\
\text { dexa } 3.3 \% \text { vs. } \\
6.1 \% \text { SOC }\end{array}$ \\
\hline
\end{tabular}


Table 5. Cont.

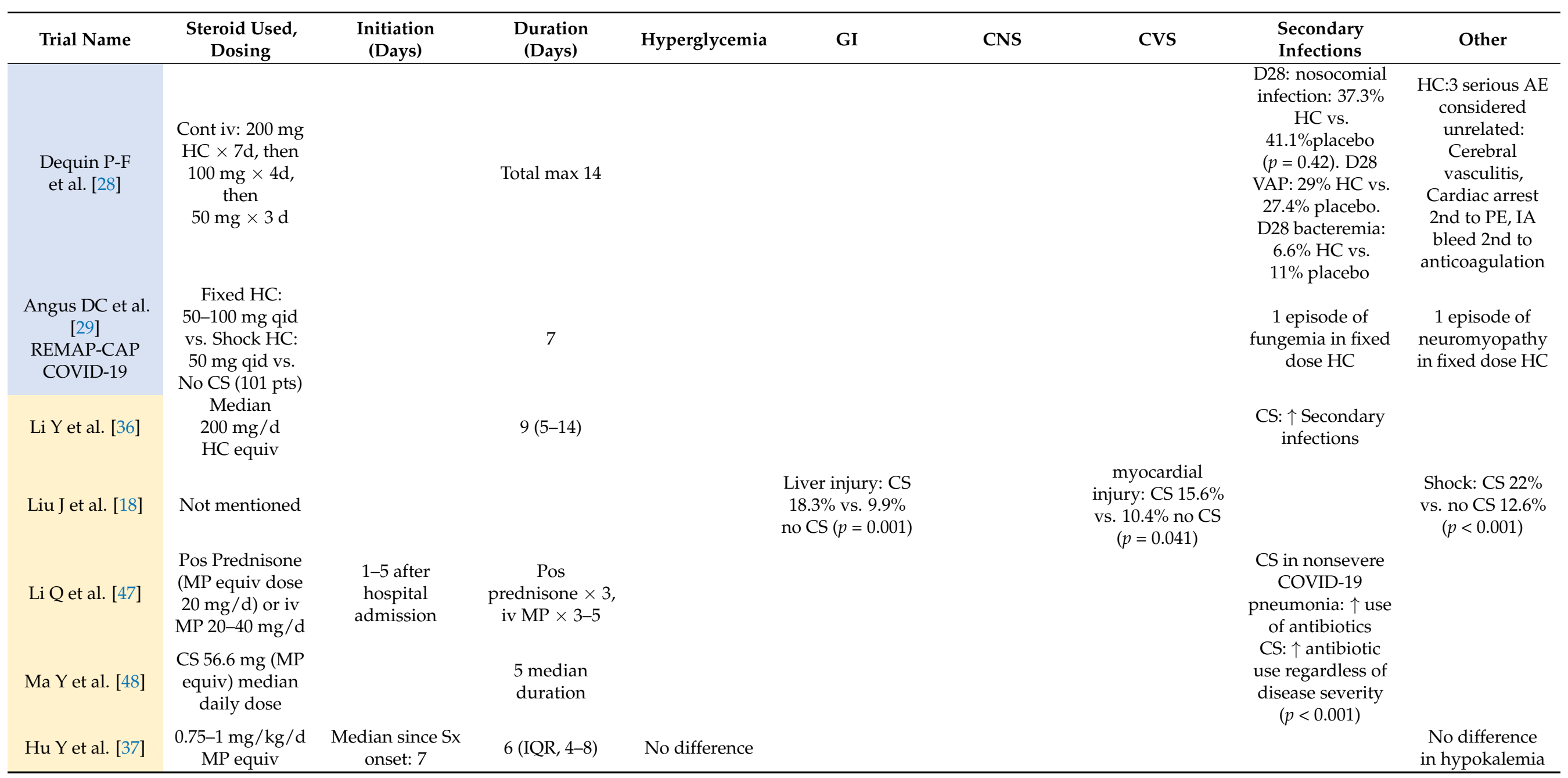


Table 5. Cont.

\begin{tabular}{|c|c|c|c|c|c|c|c|c|c|}
\hline Trial Name & $\begin{array}{c}\text { Steroid Used, } \\
\text { Dosing }\end{array}$ & $\begin{array}{l}\text { Initiation } \\
\text { (Days) }\end{array}$ & $\begin{array}{c}\text { Duration } \\
\text { (Days) }\end{array}$ & Hyperglycemia & GI & CNS & CVS & $\begin{array}{l}\text { Secondary } \\
\text { Infections }\end{array}$ & Other \\
\hline Li Y et al. [45] & $\begin{array}{c}\text { MP } 0.75-1 \\
\mathrm{mg} / \mathrm{kg} / \mathrm{d} \times 3 \mathrm{~d}, \\
\text { then } \\
20 \mathrm{mg} \times 3 \mathrm{~d} \text { vs. } \\
\text { (no MP and } \\
\text { rescue CS) }\end{array}$ & $\begin{array}{l}\text { Early (according } \\
\text { to LDH and } \\
\text { radiographic } \\
\text { progression) }\end{array}$ & $\leq 7$ & & & $\begin{array}{l}\text { No difference in } \\
\text { psychosis }\end{array}$ & & $\begin{array}{l}\text { No difference in } \\
\text { secondary } \\
\text { infections }\end{array}$ & $\begin{array}{c}\text { No difference in } \\
\text { osteoporosis, } \\
\text { avascular } \\
\text { necrosis }\end{array}$ \\
\hline $\begin{array}{l}\text { Buetti N } \\
\text { et al. [77] }\end{array}$ & $\begin{array}{l}\text { Matched case- } \\
\text { control study } \\
\text { COVID-19 vs. } \\
\text { non-COVID-19 } \\
\text { ICU pts }\end{array}$ & & & & & & & $\begin{array}{c}\text { COVID-19 pts: } \uparrow \\
\text { BSI probability, } \\
\text { esp after } 7 \mathrm{~d} \text { of } \\
\text { ICU admission } \\
\text { compared to } \\
\text { non-COVID-19 } \\
\text { ICU pts } \\
(p<0.00001) . \\
\text { COVID-19 pts: } \\
\text { significantly } \uparrow \\
\text { ICU-BSI risk if } \\
\text { received anti-IL-1 } \\
\text { or anti-IL-6 (sHR } \\
\text { 3.20, } 95 \% \text { CI } \\
1.31-7.81, \\
p=0.011) \text { but not } \\
\text { in pts who } \\
\text { received CS. }\end{array}$ & \\
\hline $\begin{array}{l}\text { Sterne JAC et al. } \\
\text { REACT [23] }\end{array}$ & $\begin{array}{l}\text { Different CS in } \\
\text { different } \\
\text { schemes }\end{array}$ & & & & & & & & $\begin{array}{l}\text { No difference in } \\
\text { serious AEs }\end{array}$ \\
\hline Van Paassen [25] & $\begin{array}{l}\text { Diverse CS } \\
\text { strategies }\end{array}$ & & $5-10$ & & & & & $\begin{array}{c}\text { CS: } \uparrow \text { use of } \\
\text { antibiotics and } \uparrow \\
\text { secondary } \\
\text { infections } \\
\text { or sepsis }\end{array}$ & \\
\hline
\end{tabular}

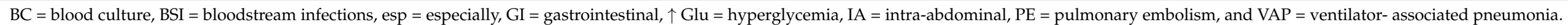
$\mathrm{CNS}=$ central nervous system; CVS: cardiovascular system. 


\section{Conclusions}

In conclusion, dexamethasone has gained a major role in the therapeutic algorithm of patients with COVID-19 pneumonia requiring supplemental oxygen or on mechanical ventilation. Its wide anti-inflammatory action seems to form the basis for its beneficial action, taming the overwhelming "cytokine storm". Amid a plethora of scientific research on the therapeutic options for COVID-19, there are still unanswered questions about the right timing, right dosing, and right duration of corticosteroids. Lastly, since medicines treat patients, we urgently need more evidence on the safety of corticosteroids on specific patient populations who may be at risk for more complications.

Author Contributions: V.R. and N.R. conceived, anddesigned the structure of the text and approved the final version. E.K., V.C., P.S. and A.K. (Alexandra Kote), contributed to the writing of the manuscript. I.V. and A.K. (Antonia Koutsouko) have read and approved the final version of the manuscript. All authors have read and agreed to the published version of the manuscript.

Funding: This research received no external funding.

Institutional Review Board Statement: Not applicable.

Informed Consent Statement: Not applicable.

Data Availability Statement: Not applicable.

Conflicts of Interest: The authors declare no conflict of interest.

\section{References}

1. Chen, N.; Zhou, M.; Dong, X.; Qu, J.; Gong, F.; Han, Y.; Qiu, Y.; Wang, J.; Liu, Y.; Wei, Y.; et al. Epidemiological and clinical characteristics of 99 cases of 2019 novel coronavirus pneumonia in Wuhan, China: A descriptive study. Lancet 2020, 395, 507-513. [CrossRef]

2. Huang, C.; Wang, Y.; Li, X.; Ren, L.; Zhao, J.; Hu, Y.; Zhang, L.; Fan, G.; Xu, J.; Gu, X.; et al. Clinical features of patients infected with 2019 novel coronavirus in Wuhan, China. Lancet 2020, 395, 497-506. [CrossRef]

3. Zhu, N.; Zhang, D.; Wang, W.; Li, X.; Yang, B.; Song, J.; Zhao, X.; Huang, B.; Shi, W.; Lu, R.; et al. A Novel Coronavirus from Patients with Pneumonia in China, 2019. China Novel Coronavirus Investigating and Research Team. N. Engl. J. Med. 2020, 382, 72. [CrossRef]

4. Guan, W.J.; Ni, Z.Y.; Hu, Y.; Liang, W.H.; Ou, C.Q.; He, J.X.; Liu, L.; Shan, H.; Lei, C.L.; Hui, D.S.; et al. China Medical Treatment Expert Group for COVID-19. Clinical Characteristics of Coronavirus Disease 2019 in China. N. Engl. J. Med. 2020, 382, 1708-1720. [CrossRef] [PubMed]

5. Hadjadj, J.; Yatim, N.; Barnabei, L.; Corneau, A.; Boussier, J.; Smith, N.; Péré, H.; Charbit, B.; Bondet, V.; Chenevier-Gobeaux, C.; et al. Impaired type I interferon activity and inflammatory responses in severe COVID-19 patients. Science 2020, 369, 718-724. [CrossRef]

6. Rovina, N.; Galani, I.E.; Lampropoulou, V.; Triantafyllia, V.; Manioudaki, M.; Pavlos, E.; Koukaki, E.; Fragkou, P.C.; Panou, V.; Rapti, V.; et al. Untuned antiviral immunity in COVID-19 revealed by temporal type I/III interferon patterns and flu comparison. Nat. Immunol. 2021, 22, 32-40.

7. Giamarellos-Bourboulis, E.J.; Netea, M.G.; Rovina, N.; Akinosoglou, K.; Antoniadou, A.; Antonakos, N.; Damoraki, G.; Gkavogianni, T.; Adami, M.-E.; Katsaounou, P.; et al. Complex Immune Dysregulation in COVID-19 Patients with Severe Respiratory Failure. Cell Host Microbe 2020, 27, 992-1000. [CrossRef] [PubMed]

8. Meffre, E.; Iwasaki, A. Interferon deficiency can lead to severe COVID. Nature 2020, 587, 374-376. [CrossRef] [PubMed]

9. Mehta, P.; McAuley, D.F.; Brown, M.; Sanchez, E.; Tattersall, R.S.; Manson, J.J. COVID-19: Consider cytokine storm syndromes and immunosuppression. HLH Across Speciality Collaboration UK. Lancet 2020, 395, 1033-1034. [CrossRef]

10. World Health Organization. Clinical Management of COVID-19. 2020. Available online: https://apps.who.int/iris/rest/ bitstreams /1278777/retrieve (accessed on 1 April 2021).

11. Yang, X.; Yu, Y.; Xu, J.; Shu, H.; Liu, H.; Wu, Y.; Zhang, L.; Yu, Z.; Fang, M.; Yu, T.; et al. Clinical course and outcomes of critically ill patients with SARS-CoV-2 pneumonia in Wuhan, China: A single-center, retrospective, observational study. Lancet Respir. Med. 2020, 8, 475-481. [CrossRef]

12. Shang, L.; Zhao, J.; Yi, H.; Du, R.; Cao, B. On the use of corticosteroids for 2019-nCoV pneumonia. Lancet 2020, 395, 683-684. [CrossRef]

13. Corral-Gudino, L.; Bahamonde, A.; Arnaiz-Revillas, F.; Gómez-Barquero, J.; Abadía-Otero, J.; García-Ibarbia, C.; Mora, V.; Cerezo-Hernández, A.; Hernández, J.L.; López-Muñíz, G.; et al. GLUCOCOVID investigators. Methylprednisolone in adults hospitalized with COVID-19 pneumonia: An open-label randomized trial (GLUCOCOVID). Wien. Klin. Wochenschr. 2021, 133, 303-311. [CrossRef] 
14. Wu, C.; Hou, D.; Du, C.; Cai, Y.; Zheng, J.; Xu, J.; Chen, X.; Chen, C.; Hu, X.; Zhang, Y.; et al. Corticosteroid therapy for coronavirus disease 2019-related acute respiratory distress syndrome: A cohort study with propensity score analysis. Crit. Care 2020, 24, 643. [CrossRef] [PubMed]

15. Alhazzani, W.; Møller, M.H.; Arabi, Y.M.; Loeb, M.; Gong, M.N.; Fan, E.; Oczkowski, S.; Levy, M.M.; Derde, L.; Dzierba, A.; et al. Surviving Sepsis Campaign: Guidelines on the Management of Critically Ill Adults with Coronavirus Disease 2019 (COVID-19). Crit. Care Med. 2020, 48, e440-e469. [CrossRef] [PubMed]

16. Dexamethasone in hospitalized patients with COVID-19. The RECOVERY Collaborative Group. N. Engl. J. Med. 2021, 384, 693-704. [CrossRef]

17. World Health Organization. WHO Welcomes Preliminary Results about Dexamethasone Use in Treating Critically Ill COVID-19 Patients. Available online: https:/ / www.who.int/news-room/detail/16-06-2020-who-welcomes-preliminaryresults-aboutdexamethasone-use-in-treatingcritically-ill-COVID-19-patients (accessed on 18 June 2020).

18. Liu, J.; Zhang, S.; Dong, X.; Li, Z.; Xu, Q.; Feng, H.; Cai, J.; Huang, S.; Guo, J.; Zhang, L.; et al. Corticosteroid treatment in severe COVID-19 patients with acute respiratory distress syndrome. J. Clin. Investig. 2020, 130, 6417-6428. [CrossRef]

19. Lu, X.; Chen, T.; Wang, Y.; Wang, J.; Yan, F. Adjuvant corticosteroid therapy for critically ill patients with COVID-19. Crit. Care 2020, 24, 241. [CrossRef]

20. Low or High Dose of Dexamethasone in Patients with Respiratory Failure by COVID-19 (HIGHLOWDEXA). Available online: https: / / clinicaltrials.gov/ct2/show / NCT04726098 (accessed on 1 April 2021).

21. Gong, Y.; Guan, L.; Jin, Z.; Chen, S.; Xiang, G.; Gao, B. Effects of methylprednisolone on viral genomic nucleic acid negative conversion and CT imaging lesion absorption in COVID-19 patients under 50 years old. J. Med. Virol. 2020, 92, 2551. [CrossRef] [PubMed]

22. Salton, F.; Confalonieri, P.; Meduri, G.U.; Santus, P.; Harari, S.; Scala, R.; Lanini, S.; Vertui, V.; Oggionni, T.; Caminati, A.; et al Prolonged low-dose methylprednisolone in patients with severe COVID-19 pneumonia. Open Forum Infect. Dis. 2020. [CrossRef]

23. Sterne, J.A.C.; Murthy, S.; Diaz, J.V.; Slutsky, A.S.; Villar, J.; Angus, D.C.; Annane, D.; Azevedo, L.C.; Berwanger, O.; Cavalcanti, A.B.; et al. WHO Rapid Evidence Appraisal for COVID-19 Therapies (REACT) Working Group. Association between Administration of Systemic Corticosteroids and Mortality among Critically Ill Patients with COVID-19: A Meta-analysis. JAMA 2020, 324, 1330.

24. Pasin, L.; Navalesi, P.; Zangrillo, A.; Kuzovlev, A.; Likhvantsev, V.; Hajjar, L.A.; Fresilli, S.; Lacerda, M.V.G.; Landoni, G. Corticosteroids for patients with coronavirus disease 2019 (COVID-19) with different disease severity: A meta-analysis of randomized clinical trials. J. Cardiothor. Vasc. Anesth. 2021, 35, 578. [CrossRef]

25. Van Paassen, J.; Vos, J.S.; Hoekstra, E.M.; Neumann, K.M.I.; Boot, P.C.; Arbous, S.M. Corticosteroid use in COVID-19 patients: A systematic review and meta-analysis on clinical outcomes. Crit. Care 2020, 24, 696. [CrossRef] [PubMed]

26. Cano, E.J.; Fuentes, X.F.; Campioli, C.C.; O’Horo, J.C.; Abu Saleh, O.; Odeyemi, Y.; Yadav, H.; Temesgen, Z. Impact of corticosteroids in coronavirus disease 2019 outcomes. Chest 2021, 159, 1019. [CrossRef]

27. Tomazini, B.M.; Maia, I.S.; Cavalcanti, A.B.; Berwanger, O.; Rosa, R.G.; Veiga, V.C.; Avezum, A.; Lopes, R.D.; Bueno, F.R.; Silva, M.V.; et al. Effect of dexamethasone on days alive and ventilator-free in patients with moderate or severe acute respiratory distress syndrome and COVID-19: The CoDEX randomized clinical trial. JAMA 2020, 324, 1307-1316. [CrossRef]

28. Dequin, P.-F.; Heming, N.; Meziani, F.; Plantefève, G.; Voiriot, G.; Badié, J.; François, B.; Aubron, C.; Ricard, J.D.; Ehrmann, S.; et al. Effect of Hydrocortisone on 21-Day Mortality or Respiratory Support among Critically Ill Patients with COVID-19: A Randomized Clinical Trial. JAMA 2020, 324, 1298-1306. [CrossRef] [PubMed]

29. Angus, D.C.; Derde, L.; Al-Beidh, F.; Annane, D.; Arabi, Y.; Beane, A.; van Bentum-Puijk, W.; Berry, L.; Bhimani, Z.; Bonten, M.; et al. Effect of Hydrocortisone on Mortality and Organ Support in Patients with Severe COVID-19: The REMAP-CAP COVID-19 Corticosteroid Domain Randomized Clinical Trial. JAMA 2020, 324, 1317-1329. [PubMed]

30. Jeronimo, C.M.P.; Farias, M.E.L.; Val, F.F.A.; Sampaio, V.S.; Alexandre, M.A.A.; Melo, G.C.; Safe, I.P.; Borba, M.G.S.; Netto, R.L.A.; Maciel, A.B.S.; et al. Methylprednisolone as adjunctive therapy for patients hospitalized with coronavirus disease 2019 (COVID-19; MetCOVID): A randomized, double-blind, phase IIb, placebo-controlled trial. Clin. Infect. Dis. 2020. [CrossRef] [PubMed]

31. Wu, C.; Chen, X.; Cai, Y.; Xia, J.; Zhou, X.; Xu, S.; Huang, H.; Zhang, L.; Zhou, X.; Du, C.; et al. Risk Factors Associated with Acute Respiratory Distress Syndrome and Death in Patients with Coronavirus Disease 2019 Pneumonia in Wuhan, China. JAMA Intern. Med. 2020, 180, 934-943. [CrossRef]

32. Fernández-Cruz, A.; Ruiz-Antorán, B.; Muñoz-Gómez, A.; Sancho-Lopez, A.; Mills-Sanchez, P.; Centeno-Soto, G.A.; BlancoAlonso, S.; Javaloyes-Garachana, L.; Galan-Gomez, A.; Valencia-Alijo, A.; et al. A Retrospective Controlled Cohort Study of the Impact of Glucocorticoid Treatment in SARS-CoV-2 Infection Mortality. Antimicrob. Agents Chemother. 2020, 64, e01168-20. [CrossRef]

33. Keller, M.J.; Kitsis, E.A.; Arora, S.; Chen, J.-T.; Agarwal, S.; Ross, M.J.; Tomer, Y.; Southern, W. Effect of systemic glucocorticoids on mortality or mechanical ventilation in patients with COVID-19. J. Hosp. Med. 2020, 15, 489. [CrossRef]

34. Zhou, W.; Liu, Y.; Tian, D.; Wang, C.; Wang, S.; Cheng, J.; Hu, M.; Fang, M.; Gao, Y. Potential benefits of precise corticosteroids therapy for severe 2019-nCoV pneumonia. Signal Transduct. Target. Ther. 2020, 5, 18. [CrossRef]

35. Wang, Y.; Jiang, W.; He, Q.; Wang, C.; Wang, B.; Zhou, P.; Dong, N.; Tong, Q. A retrospective cohort study of methylprednisolone therapy in severe patients with COVID-19 pneumonia. Signal Transduct. Target. Ther. 2020, 5, 57. [CrossRef] [PubMed] 
36. Li, Y.; Meng, Q.; Rao, X.; Wang, B.; Zhang, X.; Dong, F.; Yu, T.; Li, Z.; Feng, H.; Zhang, J.; et al. Corticosteroid therapy in critically ill patients with COVID-19: A multicenter retrospective study. Crit. Care 2020, 24, 698. [CrossRef] [PubMed]

37. Hu, Y.; Wang, T.; Hu, Z.; Wang, X.; Zhang, Z.; Li, L.; Peng, P. Clinical efficacy of glucocorticoids on the treatment of patients with COVID-19 pneumonia: A single center experience. Biomed. Pharmacother. 2020, 130, 110529. [CrossRef] [PubMed]

38. Ma, Q.; Qi, D.; Deng, X.Y.; Yuan, G.D.; Tian, W.G.; Cui, Y.; Yan, X.F.; Wang, D.X. Corticosteroid therapy for patients with severe novel Coronavirus disease 2019. Eur. Rev. Med. Pharmacol. Sci. 2020, $24,8194$.

39. Albani, F.; Fusina, F.; Granato, E.; Capotosto, C.; Ceracchi, C.; Gargaruti, R.; Santangelo, G.; Schiavone, L.; Taranto, M.S.; Tosati, C.; et al. Corticosteroid treatment has no effect on hospital mortality in COVID-19 patients. Sci. Rep. 2021, 11, 1015. [CrossRef]

40. Wu, J.; Huang, J.; Zhu, G.; Liu, Y.; Xiao, H.; Zhou, Q.; Si, X.; Yi, H.; Wang, C.; Yang, D.; et al. Systematic corticosteroids and mortality in severe and critical COVID-19 patients in Wuhan, China. J. Clin. Endocrinol. Metab. 2020, 105, 12. [CrossRef]

41. Li, X.; Xu, S.; Yu, M.; Wang, K.; Tao, Y.; Zhou, Y.; Shi, J.; Zhou, M.; Wu, B.; Yang, Z.; et al. Risk factors for severity and mortality in adult COVID-19 in-patients in Wuhan. J. Allergy Clin. Immunol. 2020, 146, 110. [CrossRef] [PubMed]

42. Tang, X.; Feng, Y.-M.; Ni, J.-X.; Zhang, J.Y.; Liu, L.M.; Hu, K.; Wu, X.Z.; Zhang, J.X.; Chen, J.W.; Zhang, J.C.; et al. Early use of corticosteroid may prolong SARS-CoV-2 shedding in non-intensive care patients with COVID-19 pneumonia: A multicenter-single, blind, randomized control trial. Respiration 2021, 100, 116.

43. Papamanoli, A.; Yoo, J.; Grewal, P.; Predun, W.; Hotelling, J.; Jacob, R.; Mojahedi, A.; Skopicki, H.A.; Mansour, M.; Marcos, L.A.; et al. High-dose methylprednisolone in nonintubated patients with severe COVID-19 pneumonia. Eur. J. Clin. Investig. 2021, 51, e13458. [CrossRef]

44. Zha, L.; Li, S.; Pan, L.; Tefsen, B.; Li, Y.; French, N.; Chen, L.; Yang, G.; Villanueva, E.V. Corticosteroid treatment of patients with coronavirus disease 2019 (COVID-19). Med. J. Aust. 2020, 212, 416. [CrossRef]

45. Li, Y.; Zhou, X.; Li, T.; Chan, S.; Yu, Y.; Ai, J.W.; Zhang, H.; Sun, F.; Zhang, Q.; Zhu, L.; et al. Corticosteroid prevents COVID-19 progression within its therapeutic window: A multicenter proof-of-concept observational study. Emerg. Microbe. Infect. 2020, 9, 1869. [CrossRef] [PubMed]

46. Yuan, M.; Xu, X.; Xia, D.; Tao, Z.; Yin, W.; Tan, W.; Hu, Y.; Song, C. Effects of corticosteroid treatment for non-severe COVID-19 pneumonia: A propensity score-based analysis. Shock 2020, 54, 638. [CrossRef]

47. Li, Q.; Li, W.; Jin, Y.; Xu, W.; Huang, C.; Li, L.; Huang, Y.; Fu, Q.; Chen, L. Efficacy evaluation of early, low-dose, short-term corticosteroids in adults hospitalized with non-severe COVID-19 pneumonia: A retrospective cohort study. Infect. Dis. 2020, $9,823$.

48. Ma, Y.; Zheng, H.; Zhan, Z.; Lu, H.; Zeng, Z.; He, C.; Liu, X.; Chen, C.; Qin, Q.; He, J.; et al. Corticosteroid use in the treatment of COVID-19: A multicenter retrospective study in Hunan, China. Front. Pharm. 2020, 11, 1198. [CrossRef] [PubMed]

49. Li, S.; Hu, Z.; Song, X. High dose but not low dose corticoids potentially delay viral shedding of patients with COVID-19. Clin. Infect. Dis. 2020. [CrossRef]

50. Waljee, A.K.; Rogers, M.A.M.; Lin, P.; Singal, A.G.; Stein, J.D.; Marks, R.M.; Ayanian, J.Z.; Nallamothu, B.K. Short term use of oral corticosteroids and related harms among adults in the United States: Population based cohort study. BMJ 2017, 357, J1415. [CrossRef]

51. Fang, X.; Mei, Q.; Yang, T.; Li, L.; Wang, Y.; Tong, F.; Geng, S.; Pan, A. Low-dose corticosteroid therapy does not delay viral clearance in patients with COVID-19. J. Infect. 2020, 81, 147-178. [CrossRef]

52. Sanders, J.M.; Monogue, M.L.; Jodlowski, T.Z.; Cutrell, J.B. Pharmacologic treatments for coronavirus disease 2019 (COVID-19): A review. J. Am. Med. Assoc. 2020, 323, 1824. [CrossRef]

53. Weikum, E.R.; Knuesel, M.T.; Ortlund, E.A.; Yamamoto, K.R. Glucocorticoid receptor control of transcription:precision and plasticity via allostery. Nat. Rev. Mol. Cell Biol. 2017, 18, 159-174. [CrossRef]

54. Rhen, T.; Cidlowski, J.A. Antiinflammatory action of glucocorticoids-New mechanisms for old drugs. N. Engl. J. Med. 2005, 353, 1711-1723. [CrossRef]

55. Song, P.; Li, W.; Xie, J.; Hou, Y.; You, C. Cytokine storm induced by SARS-CoV-2. Clin. Chim. Acta 2020, 509, 280-287. [CrossRef]

56. Youssef, J.; Novosad, S.A.; Winthrop, K.L. Infection risk and safety of corticosteroid use. Rheum. Dis. Clin. 2016, 42, 157-176. [CrossRef]

57. Coutinho, A.E.; Chapman, K.E. The anti-inflammatory and immunosuppressive effects of glucocorticoids, recent developments and mechanistic insights. Mol. Cell Endocrinol. 2011, 335, 2-13. [CrossRef]

58. Pyrillou, K.; Chairakaki, A.D.; Tamvakopoulos, C.; Andreakos, E. Dexamethasone induces omega3-derived immunoresolvents driving resolution of allergic airway inflammation. J. Allergy Clin. Immunol. 2018, 142, 691-695. [CrossRef] [PubMed]

59. Serhan, C.N. Pro-resolving lipid mediators are leads for resolution physiology. Nature 2014, 510, 92-101. [CrossRef]

60. van Zaane, B.; Nur, E.; Squizzato, A.; Gerdes, V.E.A.; Büller, H.R.; Dekkers, O.M.; Brandjes, D.P.M. Systematic review on the effect of glucocorticoid use on procoagulant, anti-coagulant and fibrinolytic factors. J. Thromb. Haemost. 2010, 8, 2483-2493. [CrossRef] [PubMed]

61. Wang, K.; Zhang, Z.; Yu, M.; Tao, Y.; Xie, M. 15-day mortality and associated risk factors for hospitalized patients with COVID-19 in Wuhan, China: An ambispective observational cohort study. Intensive Care Med. 2020. [CrossRef] [PubMed]

62. Corticosteroid Dose Equivalents. Available online: https://emedicine.medscape.com/article/2172042-overview (accessed on 1 April 2021). 
63. Mager, D.E.; Moledina, N.; Jusko, W.J. Relative immunosuppressive potency of therapeutic corticosteroids measured by whole blood lymphocyte proliferation. J. Pharm. Sci. 2003, 92, 1521-1525. [CrossRef]

64. Cechin, S.R.; Buchwald, P. Effects of representative glucocorticoids on TNF $\alpha$ - and CD40L-induced NF-K activation in sensor cells. Steroids 2014, 85, 36-43. [CrossRef] [PubMed]

65. NIH. COVID-19 Treatment guidelines. Available online: https://www.covid19treatmentguidelines.nih.gov/immunomodulators/ corticosteroids / (accessed on 14 March 2021).

66. Siddiqi, H.K.; Mehra, M.R. COVID-19 Illness in native and immunosuppressed states: A clinical-therapeutic staging proposal. J. Heart Lung Transplant. 2020, 39, 405-407. [CrossRef]

67. Villar, J.; Ferrando, C.; Martinez, D.; Ambrós, A.; Muñoz, T.; Soler, J.A. Dexamethasone in ARDS Network. Dexamethasone treatment for the acute respiratory distress syndrome: A multicentre, randomised controlled trial. Lancet Respir. Med. 2020, 8 , 267-276. [CrossRef]

68. Shabalin, I.G.; Czub, M.P.; Majorek, K.A.; Brzezinski, D.; Grabowski, M.; Cooper, D.R.; Panasiuk, M.; Chruszcz, M.; Minor, W. Molecular determinants of vascular transport of dexamethasone in COVID-19 therapy. IUCrJ 2020, 7, 1048-1058. [CrossRef] [PubMed]

69. Pan, S.-D.; Zhu, L.-L.; Chen, M.; Xia, P.; Zhou, Q. Weight-based dosing in medication use: What should we know? Patient Prefer. Adherence 2016, 10, 549. [PubMed]

70. Chrousos, G.P.; Meduri, G.U. Critical COVID-19 disease, homeostasis and the "surprise" of effective glucocorticoid therapy. Clin Immunol. 2020, 219, 108550. [CrossRef] [PubMed]

71. Meduri, G.U.; Chrousos, G.P. General adaptation in critical illness: Glucocorticoid receptor-alpha, master regulator of homeostatic corrections. Front. Endocrinol. 2020, 11, 161. [CrossRef]

72. Gogali, A.; Kyriakopoulos, C.; Kostikas, K. Corticosteroids in COVID-19: One size does not fit all. Eur. Respir. J. 2021, in press [CrossRef]

73. Xu, K.; Chen, Y.; Yuan, J.; Yi, P.; Ding, C.; Wu, W.; Li, Y.; Ni, Q.; Zou, R.; Li, X.; et al. Factors associated with prolonged viral RNA shedding in patients with coronavirus disease 2019 (COVID-19). Clin. Infect. Dis. 2020, 71, 799. [CrossRef]

74. Shi, D.; Wu, W.; Wang, Q.; Xu, K.; Xie, J.; Wu, J.; Lv, L.; Sheng, J.; Guo, J.; Wang, K.; et al. Clinical characteristics and factors accociated with long-term viral excretion in patients with severe acute respiratory syndrome Coronavirus infection: A single-center 28-day study. J. Infect. Dis. 2020, 222, 910. [CrossRef]

75. Yao, T.-C.; Huang, Y.-W.; Chang, S.-M.; Tsai, S.-Y.; Wu, A.C.; Tsai, H.-J. Association between oral corticosteroid bursts and severe adverse events. A nation population-based cohort study. Ann. Intern. Med. 2020, 173, 325. [CrossRef]

76. Buetti, N.; Ruckly, S.; Montmollin, E.; Reignier, J.; Terzi, N.; Cohen, Y.; Shiami, S.; Dupuis, C.; Timsit, J.-F. COVID19 increased the risk of ICU-acquired bloodstream infections: A case-cohort study from the multicentric OUTCOMEREA network. Intensive Care Med. 2021. [CrossRef]

77. Giacobbe, D.R.; Battaglini, D.; Ball, L.; Brunetti, I.; Bruzzone, B.; Codda, G.; Crea, F.; De Maria, A.; Dentone, C.; Di Biagio, A.; et al Bloodstream infections in critically ill patients with COVID-19. Eur. J. Clin. Investig. 2020, 50, e13319. [CrossRef] [PubMed]

78. Tudesq, J.-J.; Peyrony, O.; Lemiale, V.; Azoulay, E. Invasive pulmonary aspergillosis in nonimmunocompromised hosts. Semin. Respir. Crit. Care Med. 2019, 40, 540. [CrossRef]

79. Armstrong-James, D.; Youngs, J.; Bicanic, T.; Abdolrasouli, A.; Denning, D.W.; Johnson, E.; Mehra, V.; Pagliuca, T.; Patel, B.; Rhodes, J.; et al. Confronting and mitigating the risk of COVID-19 associated pulmonary aspergillosis. Eur. Respir. J. 2020, 56, 2002554. [CrossRef]

80. Ahmadikia, K.; Hashemi, S.J.; Khodavaisi, S.; Getso, M.I.; Alijani, N.; Badali, H.; Mirhendi, H.; Salehi, M.; Tabari, A.; Ardehali, M.M.; et al. The double-edged sword of systemic cosrticosteroid therapy in viral pneumonia: A case report and comparative review of influenza-associated mucormycosis versus COVID-19 associated mucormycosis. Mycoses 2021. [CrossRef]

81. Yang, M.; Zhang, Y.; Chen, H.; Lin, J.; Zeng, J.; Xu, Z. Inhaled corticosteroids and risk of upper respiratory tract infection in patients with asthma: A meta-analysis. Infection 2019, 47, 377-385. [CrossRef] [PubMed]

82. Yang, M.; Chen, H.; Zhang, Y.; Du, Y.; Xu, Y.; Jiang, P.; Xu, Z. Long-term use of inhaled corticosteroids and risk of upper respiratory tract infection in chronic obstructive pulmonary disease: A meta-analysis. Inhal. Toxicol. 2017, 29, 219-226. [CrossRef] [PubMed]

83. Yang, I.A.; Clarke, M.S.; Sim, E.H.; Fong, K.M. Inhaled corticosteroids for stable chronic obstructive pulmonary disease. Cochrane Database Syst. Rev. 2012, 7, CD002991. [CrossRef]

84. Contoli, M.; Pauletti, A.; Rossi, M.R.; Spanevello, A.; Casolari, P.; Marcellini, A.; Forini, G.; Gnesini, G.; Marku, B.; Barnes, N.; et al. Long-term effects of inhaled corticosteroids on sputum bacterial and viral loads in COPD. Eur. Respir. J. 2017, 50, 1700451. [CrossRef]

85. Matsuyama, S.; Kawase, M.; Nao, N.; Shirato, K.; Ujike, M.; Kamitani, W.; Shimojima, M.; Fukushi, S. The inhaled corticosteroid ciclesonide blocks coronavirus RNA replication by targeting viral NSP15. BioRxiv 2020. [CrossRef]

86. Jeon, S.; Ko, M.; Lee, J.; Choi, I.; Byun, S.Y.; Park, S.; Shum, D.; Kim, S. Identification of antiviral drug candidates against SARS-CoV-2 from FDA-approved drugs. Antimicrob. Agents Chemother. 2020, 64, e00819-20. [CrossRef]

87. Iwabuchi, K.; Yoshie, K.; Kurakami, Y.; Takahashi, K.; Kato, Y.; Morishima, T. Therapeutic potential of ciclesonide inahalation for COVID-19 pneumonia: Report of three cases. J. Infect. Chemother. 2020, 26, 625-632. [CrossRef] [PubMed] 
88. Yamaya, M.; Nishimura, H.; Deng, X.; Sugawara, M.; Watanabe, O.; Nomura, K.; Shimotai, Y.; Momma, H.; Ichinose, M.; Kawase, T. Inhibitory effects of glycopyrronium, formoterol, and budesonide on coronavirus HCoV-229E replication and cytokine production by primary cultures of human nasal and tracheal epithelial cells. Respir. Investig. 2020, in press. [CrossRef] [PubMed]

89. Ramakrishnan, S.; Nicolau, D.V., Jr.; Langford, B. Inhaled budesonide in the treatment of early COVID-19 (STOIC): A phase 2, open-label randomized controlled trial. Lancet 2021. [CrossRef]

90. Halpin, D.M.G.; Singh, D.; Hafield, R.M. Inhaled corticosteroids and COVID-19: A systematic review and clinical perspective. Eur. Respir. J. 2020, 55, 2001009. [CrossRef] [PubMed]

91. Global Initiative for Asthma. Global Strategy for Asthma Management and Prevention. 2019. Available online: www.ginasthma. org (accessed on 1 April 2021).

92. Global Initiative for Chronic Obstructive Lung Disease (GOLD). Global Strategy for the Diagnosis, Management, and Prevention of Chronic Obstructive Pulmonary Disease. 2020. Available online: www.goldcopd.org/ (accessed on 1 April 2021). 